\title{
\#USGS
}

Prepared in cooperation with the Providence Water Supply Board

Streamflow, Water Quality, and Constituent Loads and Yields, Scituate Reservoir Drainage Area, Rhode Island, Water Year 2014

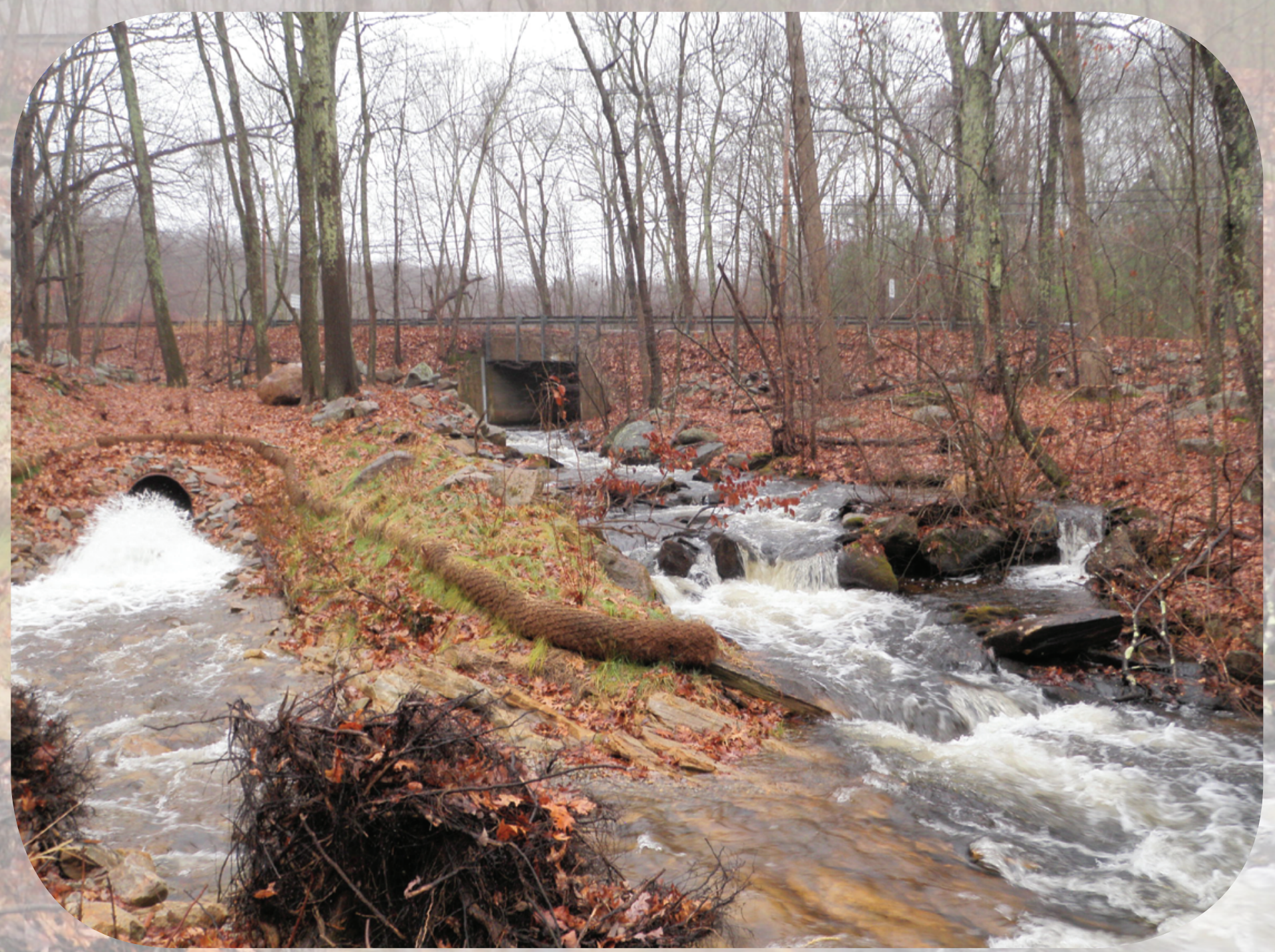

Open-File Report 2016-1051

U.S. Department of the Interior

U.S. Geological Survey 
Cover. Westconnaug Stream at Plainfield Pike, Rhode Island. Photograph by Joan Whitley. 


\section{Streamflow, Water Quality, and Constituent Loads and Yields, Scituate Reservoir Drainage Area, Rhode Island, Water Year 2014}

By Kirk P. Smith

Prepared in cooperation with the Providence Water Supply Board

Open-File Report 2016-1051 


\section{U.S. Department of the Interior SALLY JEWELL, Secretary}

\section{U.S. Geological Survey Suzette M. Kimball, Director}

\section{U.S. Geological Survey, Reston, Virginia: 2016}

For more information on the USGS - the Federal source for science about the Earth, its natural and living resources, natural hazards, and the environment-visit http://www.usgs.gov or call 1-888-ASK-USGS.

For an overview of USGS information products, including maps, imagery, and publications, visit http://store.usgs.gov.

Any use of trade, firm, or product names is for descriptive purposes only and does not imply endorsement by the U.S. Government.

Although this information product, for the most part, is in the public domain, it also may contain copyrighted materials as noted in the text. Permission to reproduce copyrighted items must be secured from the copyright owner.

Suggested citation:

Smith, K.P., 2016, Streamflow, water quality, and constituent loads and yields, Scituate Reservoir drainage area, Rhode Island, water year 2014: U.S. Geological Survey Open-File Report 2016-1051, 31 p., http://dx.doi.org/10.3133/ ofr20161051.

ISSN 2331-1258 (online) 


\section{Contents}

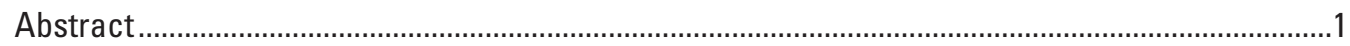

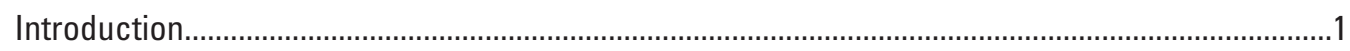

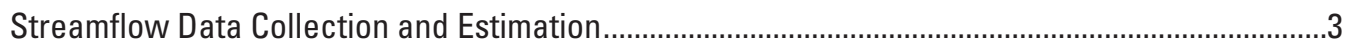

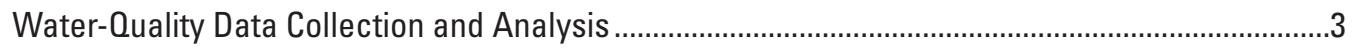

Data Collected by the U.S. Geological Survey ............................................................................

Data Collected by the Providence Water Supply Board ............................................................

Estimating Daily, Monthly, and Annual Loads and Yields.........................................................

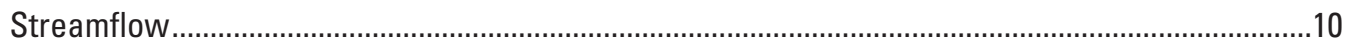

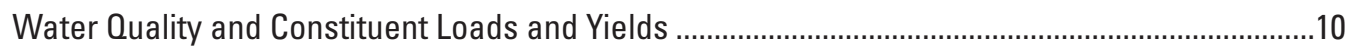

Sodium and Chloride Loads and Yields Estimated from Specific-Conductance

Monitoring Data .................................................................................................10

Physical and Chemical Properties and Daily Loads and Yields Estimated from Data

Collected by the Providence Water Supply Board .....................................................12

Physical and Chemical Properties ..................................................................................12

Constituent Concentrations and Daily Loads and Yields..................................................12

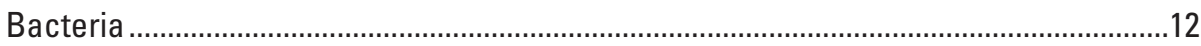

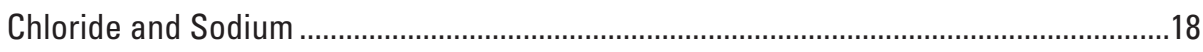

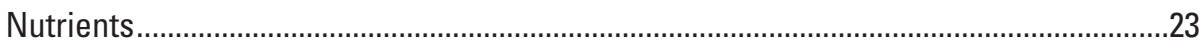

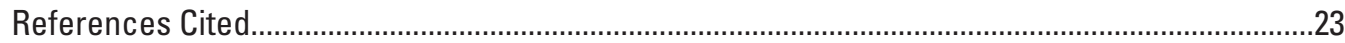

Appendix 1. Water-Quality Data Collected by the Providence Water Supply Board at 37

Monitoring Stations in the Scituate Reservoir Drainage Area, Water Year 2014 ................31

\section{Figures}

1. Map showing locations of tributary-reservoir subbasins and stations in the Scituate Reservoir drainage area, Rhode Island, 2014 .

2. Graph showing flow-duration curve and streamflow on the dates when waterquality samples were collected for the U.S. Geological Survey continuous-record streamgage on Wilbur Hollow Brook at Old Plainfield Pike near Clayville (01115297), Rhode Island, water year 2014

3. Graph showing measured daily mean streamflow for October 1, 2013, through September 30,2014, and the 10th percentile, median, and 90th percentile values of daily streamflow for October 1, 1994, through September 30, 2013, for the U.S. Geological Survey continuous-record streamgage on the Ponaganset River at South Foster (01115187) in the Scituate Reservoir drainage area, Rhode Island

4. Graph showing annual loads of chloride and sodium estimated from continuous measurements of streamflow and specific conductance for water year 2014 and associated minimum, maximum, and median annual loads for water years 2009-13 at 14 Providence Water Supply Board stations in the Scituate Reservoir drainage area, Rhode Island 


\section{Tables}

1. Providence Water Supply Board water-quality sampling stations, water-quality samples, and available streamflow and continuous-monitoring streamgages by tributary reservoir subbasin in the Scituate Reservoir drainage area, Rhode Island, October 1, 2013, to September 30, 2014.

2. Measured or estimated annual mean streamflow for tributaries in the Scituate Reservoir drainage area, Rhode Island, October 1, 2013, through September 30, 2014

3. Regression equation coefficients used to estimate concentrations of chloride and sodium from values of specific conductance for each U.S. Geological Survey monitoring station in the Scituate Reservoir drainage area, Rhode Island, October 1, 2013, through September 30, 2014

4. Daily loads of bacteria, chloride, nitrate, nitrite, and orthophosphate by tributary reservoir subbasin in the Scituate Reservoir drainage area, Rhode Island, October 1, 2013, through September 30, 2014.

5. Monthly mean concentrations of chloride and sodium estimated from continuous measurements of specific conductance in the Scituate Reservoir drainage area, Rhode Island, October 1, 2013, through September 30, $2014 .$.

6. Annual mean chloride and sodium concentrations, loads, and yields by sampling station in the Scituate Reservoir drainage area, Rhode Island, October 1, 2013, through September 30, 2014

7. Monthly estimated chloride and sodium loads by sampling station in the Scituate Reservoir drainage area, Rhode Island, October 1, 2013, through September 30, 2014

8. Median values for water-quality data collected at Providence Water Supply Board stations by tributary reservoir subbasin in the Scituate Reservoir drainage area, Rhode Island, October 1, 2013, through September 30, 2014

9. Median daily loads and yields of bacteria, chloride, nitrate, nitrite, and orthophosphate by tributary reservoir subbasin in the Scituate Reservoir drainage area,

Rhode Island, October 1, 2013, through September 30, 2014.

\section{Conversion Factors}

Inch/Pound to International System of Units

\begin{tabular}{lcl}
\hline \multicolumn{1}{c}{ Multiply } & By & To obtain \\
\hline mile $(\mathrm{mi})$ & Length & \\
\hline & 1.609 & kilometer $(\mathrm{km})$ \\
\hline square mile $\left(\mathrm{mi}^{2}\right)$ & Area & \\
\hline & 2.590 & square kilometer $\left(\mathrm{km}^{2}\right)$ \\
\hline cubic foot per second $\left(\mathrm{ft}^{3} / \mathrm{s}\right)$ & Flow rate & \\
\hline & 0.02832 & cubic meter per second $\left(\mathrm{m}^{3} / \mathrm{s}\right)$ \\
\hline ton, short $(2,000 \mathrm{lb})$ & Mass & \\
\hline
\end{tabular}




\section{Datum}

Horizontal coordinate information is referenced to North American Datum of 1983 (NAD 83).

\section{Supplemental Information}

Concentrations of chemical constituents in water are given either in milligrams per liter (mg/L) or colony forming units per 100 milliliters (CFU/100 mL).

Loads of chemical constituents in water are given either in grams or kilograms (or millions of colony forming units for bacteria) per day or year, and yields are given in grams or kilograms (or millions of colony forming units for bacteria) per day or year per square mile.

\section{Abbreviations}

CFU colony forming units

E. coli Escherichia coli

MOVE.1 Maintenance of Variance Extension type 1

NTU nephelometric turbidity units

NWIS National Water Information System

PCU platinum cobalt units

PWSB Providence Water Supply Board

RIDEM Rhode Island Department of Environmental Management

USGS U.S. Geological Survey

WY water year 



\title{
Streamflow, Water Quality, and Constituent Loads and Yields, Scituate Reservoir Drainage Area, Rhode Island, Water Year 2014
}

\author{
By Kirk P. Smith
}

\section{Abstract}

Streamflow and concentrations of sodium and chloride estimated from records of specific conductance were used to calculate loads of sodium and chloride during water year (WY) 2014 (October 1, 2013, through September 30, 2014) for tributaries to the Scituate Reservoir, Rhode Island. Streamflow and water-quality data used in the study were collected by the U.S. Geological Survey and the Providence Water Supply Board in the cooperative study. Streamflow was measured or estimated by the U.S. Geological Survey following standard methods at 23 streamgages; 14 of these streamgages are equipped with instrumentation capable of continuously monitoring water level, specific conductance, and water temperature. Water-quality samples were collected at 37 sampling stations by the Providence Water Supply Board and at 14 continuous-record streamgages by the U.S. Geological Survey during WY 2014 as part of a long-term sampling program; all stations are in the Scituate Reservoir drainage area. Water-quality data collected by the Providence Water Supply Board are summarized by using values of central tendency and are used, in combination with measured (or estimated) streamflows, to calculate loads and yields (loads per unit area) of selected water-quality constituents for WY 2014.

The largest tributary to the reservoir (the Ponaganset River, which was monitored by the U.S. Geological Survey) contributed a mean streamflow of 23 cubic feet per second to the reservoir during WY 2014. For the same time period, annual mean ${ }^{1}$ streamflows measured (or estimated) for the other monitoring stations in this study ranged from about 0.35 to about 14 cubic feet per second. Together, tributaries (equipped with instrumentation capable of continuously monitoring specific conductance) transported about 1,200,000 kilograms of sodium and 2,100,000 kilograms of chloride to the Scituate Reservoir during WY 2014; sodium and chloride yields for the tributaries ranged from 7,700 to 45,000 kilograms per year per square mile and from 12,000 to 75,000 kilograms per year per square mile, respectively.

${ }^{1}$ The arithmetic mean of the individual daily mean discharges for the year noted or for the designated period.
At the stations where water-quality samples were collected by the Providence Water Supply Board, the median of the median chloride concentrations was 24 milligrams per liter, median nitrite concentration was 0.002 milligrams per liter as nitrogen $(\mathrm{N})$, median nitrate concentration was 0.01 milligrams per liter as $\mathrm{N}$, median orthophosphate concentration was 0.07 milligrams per liter as phosphate, and median concentrations of total coliform bacteria and Escherichia coli were 320 and 20 colony forming units per 100 milliliters, respectively. The medians of the median daily loads (and yields) of chloride, nitrite, nitrate, orthophosphate, and total coliform and Escherichia coli bacteria were 62 kilograms per day (42 kilograms per day per square mile), 19 grams per day (6.1 grams per day per square mile), 79 grams per day (36 grams per day per square mile), 380 grams per day (150 grams per day per square mile), 13,000 million colony forming units per day $(8,300$ million colony forming units per day per square mile), and 1,000 million colony forming units per day (470 million colony forming units per day per square mile), respectively.

\section{Introduction}

The Scituate Reservoir is the primary source of drinking water for more than 60 percent of the population of Rhode Island. It covers about 94 square miles in parts of the towns of Cranston, Foster, Glocester, Johnston, and Scituate, Rhode Island (fig. 1). Information about the water quality of the reservoir and its tributaries is important for management of the water supply and for the protection of human health. The Providence Water Supply Board (PWSB), the agency responsible for the management and distribution of the Scituate Reservoir water supply, has been monitoring and assessing water quality in the reservoir and reservoir drainage area for more than 60 years.

Since 1993, the U.S. Geological Survey (USGS) has been cooperating with the PWSB and the Rhode Island Department of Environmental Management (RIDEM) to measure streamflow in tributaries to the Scituate Reservoir. Since 2009, 


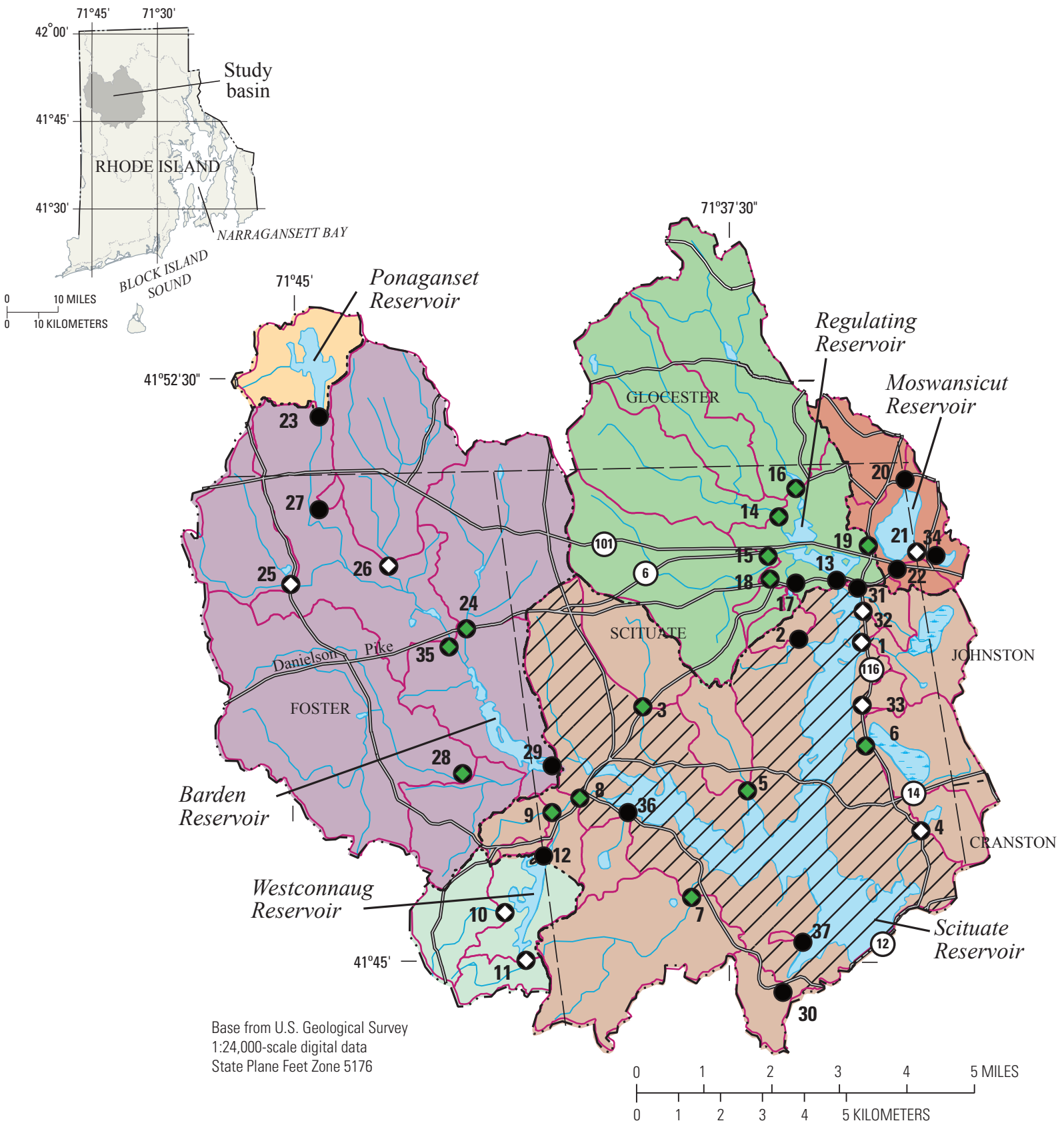

EXPLANATION

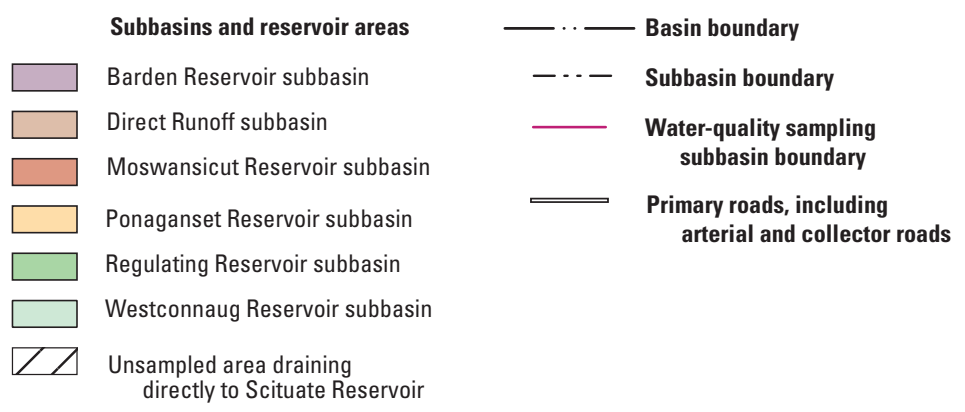

\footnotetext{
Streamflow or water-quality monitoring station and identifier

Providence Water Supply Board

22 water-quality sampling station and number

- Providence Water Supply Board water-quality

$5 \quad$ sampling station and U.S. Geological Survey

5 continuous streamgage and water-quality monitoring station

Providence Water Supply Board water-quality sampling

$4 \quad$ station and U.S. Geological Survey streamgage

U.S. Geological Survey downstream order numbers shown in table 1
}

Figure 1. Locations of tributary-reservoir subbasins and stations in the Scituate Reservoir drainage area, Rhode Island, 2014. 
streamflow has been continuously measured at 14 streamgages in the drainage area and periodically measured at 9 additional streamgages on tributaries in the drainage area. At the nine partial-record streamgages, daily mean streamflow has been estimated by using methods developed by the USGS (Hirsch, 1982). The USGS also has been continuously measuring specific conductance at 14 monitoring stations since 2009. Equations that relate specific conductance to concentrations of sodium and chloride in streamwater were developed as part of previous USGS/PWSB cooperative studies (Smith, 2015b; Nimiroski and Waldron, 2002). These equations, updated here and used together with measured (or estimated) streamflows, allow for nearly continuous estimation of sodium and chloride loads to the reservoir.

Currently (2014), the PWSB regularly collects waterquality samples from 37 tributaries, either monthly or quarterly. Water-quality results are summarized by station number and constituent or parameter in annual reports published by the PWSB. In addition, the USGS has published reports that have compiled and tabulated streamflow (measured or estimated by the USGS) and water-quality data (collected by the PWSB) (Breault and others, 2000; Nimiroski and others, 2008; Breault, 2010; Breault and Campbell, 2010a-d; Breault and Smith, 2010; Smith and Breault, 2011; Smith, 2013, 2014, 2015a).

This report presents data on streamflow, water quality, and loads and yields of selected constituents for water year (WY) $2014^{2}$ in the Scituate Reservoir drainage area. These data were collected as parts of studies done by the USGS in cooperation with the PWSB and the RIDEM. A summary of measured and estimated streamflows is presented for the 14 continuous-record and 9 partial-record streamgages in the drainage area. Estimated monthly and annual loads (and yields) of sodium and chloride are presented for the 14 streamgages at which specific conductance is continuously monitored by the USGS. Summary statistics for water-quality data collected by the PWSB for 37 sampling stations (table 1) during WY 2014 also are presented, and these data were used to calculate loads and yields of selected water-quality constituents.

\section{Streamflow Data Collection and Estimation}

Streamflow and water-quality data were collected by the USGS and the PWSB (table 1). Streamflow was measured or estimated by the USGS at 23 streamgages. Measured and estimated streamflows are necessary to estimate water volume and water-quality constituent loads and yields from tributary basins. Stream stage is measured every 10 minutes at most continuous-record streamgages. Streamflow is computed with a stage-discharge relation (known as a rating), which is

${ }^{2}$ October 1, 2013, through September 30, 2014. developed on the basis of periodic manual measurements of streamflow. Daily mean streamflow at a streamgage is calculated by dividing the total volume of water that passes the streamgage each day by 86,400 , the number of seconds in a day. Periodic manual streamflow measurements at partialrecord streamgages are used concurrently with continuousrecord measurements from streamgages in hydrologically similar drainage areas to estimate a continuous record at the partial-record streamgage. Specifically, continuous-streamflow records for the nine partial-record sites in the Scituate Reservoir drainage area were estimated by using the Maintenance of Variance Extension type 1 (MOVE.1) method, as described by Ries and Friesz (2000); data needed to estimate streamflows at partial-record sites were retrieved from the USGS National Water Information System (NWIS; http://waterdata.usgs.gov/ nwis/). The upper and lower 90-percent confidence limits for the estimated mean annual streamflows, as described by Tasker and Driver (1988), are presented in table 2. These data indicate that there is a 90-percent chance that the estimated mean annual streamflow is somewhere between the upper and lower 90-percent confidence limits.

Continuous-record streamgages were operated and maintained by the USGS during WY 2014 in cooperation with RIDEM (USGS streamgage 01115187) and the PWSB (fig. 1, table 1). Streamflow data for these streamgages were collected at 10- or 15-minute intervals (near-real-time streamflow data), were updated at 1-hour intervals on the internet, and are available through the NWIS Web interface (NWIS Web; U.S. Geological Survey, 2007). Error associated with measured streamflows was generally within about 15 percent (U.S. Geological Survey, unpublished data).

\section{Water-Quality Data Collection and Analysis}

Water-quality data were collected by the USGS and the PWSB. Concentrations of sodium and chloride were estimated by the USGS from continuous or partial records of specific conductance from 14 of the 23 streamgages. Water-quality samples were collected monthly or quarterly at 37 sampling stations in the Scituate Reservoir drainage area by the PWSB during WY 2014 as part of a long-term sampling program (appendix 1). Daily loads of bacteria, chloride, nitrite, nitrate, and orthophosphate were calculated for 23 streamgages where streamflow data were collected by the USGS and water-quality samples were collected by the PWSB. Yields were calculated by dividing load by drainage area.

\section{Data Collected by the U.S. Geological Survey}

Water quality was monitored in a periodic water-quality sampling program that included measurements by automatic specific-conductance probes. The USGS collected and 
Table 1. Providence Water Supply Board water-quality sampling stations, water-quality samples, and available streamflow and continuous-monitoring streamgages by tributary reservoir subbasin in the Scituate Reservoir drainage area, Rhode Island, October 1, 2013, to September 30, 2014.

[Alternate station names are given in parentheses for stations where different historical names were used for the same sampling location by the Providence Water

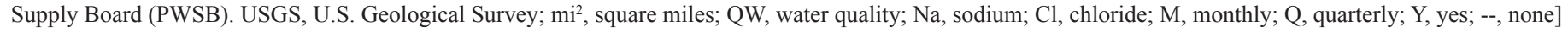

\begin{tabular}{|c|c|c|c|c|c|c|c|c|}
\hline $\begin{array}{l}\text { PWSB } \\
\text { station } \\
\text { num- } \\
\text { ber }\end{array}$ & $\begin{array}{l}\text { USGS } \\
\text { station } \\
\text { number }\end{array}$ & Station name & $\begin{array}{l}\text { Drain- } \\
\text { age } \\
\text { area } \\
\left(\mathrm{mi}^{2}\right)\end{array}$ & $\begin{array}{l}\text { Frequen- } \\
\text { cy of } \mathrm{QW} \\
\text { sample } \\
\text { collec- } \\
\text { tion }\end{array}$ & $\begin{array}{c}\text { Number of } \\
\text { samples } \\
\text { collected } \\
\text { by Provi- } \\
\text { dence } \\
\text { Water }^{1}\end{array}$ & $\begin{array}{l}\text { Daily } \\
\text { estimat- } \\
\text { ed } \mathrm{Na} \\
\text { and } \mathrm{Cl} \\
\text { loads }\end{array}$ & $\begin{array}{l}\text { Streamflow } \\
\text { availability }\end{array}$ & $\begin{array}{l}\text { Specific } \\
\text { conduc- } \\
\text { tance } \\
\text { availability }\end{array}$ \\
\hline \multicolumn{9}{|c|}{ Barden Reservoir subbasin } \\
\hline 24 & 01115190 & Dolly Cole Brook & 4.90 & $\mathrm{M}$ & 9 & $\mathrm{Y}$ & Continuous & Continuous \\
\hline 25 & 01115200 & Shippee Brook & 2.35 & Q & 2 & $\mathrm{~N}$ & Estimated & None \\
\hline 26 & 01115185 & Windsor Brook & 4.32 & Q & 3 & $\mathrm{~N}$ & Estimated & None \\
\hline 27 & 011151845 & $\begin{array}{l}\text { Unnamed Tributary to Ponaganset River } \\
\text { (Unnamed Brook B, Unnamed Brook West } \\
\text { of Windsor Brook) }\end{array}$ & 0.10 & Q & 2 & $\mathrm{~N}$ & None & None \\
\hline 28 & 01115265 & Barden Reservoir (Hemlock Brook) & 8.72 & M & 10 & $\mathrm{Y}$ & Continuous & Continuous \\
\hline 29 & 01115271 & Ponaganset River (Barden Stream) & 33.0 & M & 8 & $\mathrm{~N}$ & None & None \\
\hline 35 & 01115187 & Ponaganset River & 14.0 & M & 7 & $\mathrm{Y}$ & Continuous & Continuous \\
\hline \multicolumn{9}{|c|}{ Direct Runoff subbasin } \\
\hline 1 & 01115180 & Brandy Brook & 1.57 & M & 10 & $\mathrm{~N}$ & Estimated & None \\
\hline 2 & 01115181 & $\begin{array}{l}\text { Unnamed Tributary } 2 \text { to Scituate Reservoir } \\
\text { (Unnamed Brook North of Bullhead Brook) }\end{array}$ & 0.15 & Q & 2 & $\mathrm{~N}$ & None & None \\
\hline 3 & 01115280 & Cork Brook & 1.79 & M & 8 & $\mathrm{Y}$ & Continuous & Continuous \\
\hline 4 & 01115400 & Kent Brook (Betty Pond Stream) & 0.85 & M & 9 & $\mathrm{~N}$ & Estimated & None \\
\hline 5 & 01115184 & Spruce Brook & 1.22 & Q & 3 & $\mathrm{Y}$ & Continuous & Continuous \\
\hline 6 & 01115183 & Quonapaug Brook & 1.96 & M & 10 & $\mathrm{Y}$ & Continuous & Continuous \\
\hline 7 & 01115297 & Wilbur Hollow Brook & 4.32 & M & 10 & $\mathrm{Y}$ & Continuous & Continuous \\
\hline 8 & 01115276 & Westconnaug Brook (Westconnaug Reservoir) & 5.18 & M & 7 & Y & Continuous & Continuous \\
\hline 9 & 01115275 & Bear Tree Brook & 0.62 & Q & 2 & $\mathrm{Y}$ & Continuous & Continuous \\
\hline 30 & 01115350 & $\begin{array}{l}\text { Unnamed Tributary } 4 \text { to Scituate Reservoir } \\
\text { (Coventry Brook, Knight Brook) }\end{array}$ & 0.78 & Q & 2 & $\mathrm{~N}$ & None & None \\
\hline 31 & 01115177 & Toad Pond & 0.04 & Q & 1 & $\mathrm{~N}$ & None & None \\
\hline 32 & 01115178 & $\begin{array}{l}\text { Unnamed Tributary } 1 \text { to Scituate Reservoir } \\
\text { (Pine Swamp Brook) }\end{array}$ & 0.45 & Q & 2 & $\mathrm{~N}$ & Estimated & None \\
\hline 33 & 01115182 & $\begin{array}{l}\text { Unnamed Tributary } 3 \text { to Scituate Reservoir } \\
\text { (Hall's Estate Brook) }\end{array}$ & 0.28 & Q & 2 & $\mathrm{~N}$ & Estimated & None \\
\hline 36 & -- & Outflow from King Pond & 0.77 & Q & 1 & $\mathrm{~N}$ & None & None \\
\hline 37 & -- & Fire Tower Stream & 0.15 & Q & 1 & $\mathrm{~N}$ & None & None \\
\hline \multicolumn{9}{|c|}{ Moswansicut Reservoir subbasin } \\
\hline 19 & 01115170 & $\begin{array}{l}\text { Moswansicut Reservoir (Moswansicut Stream } \\
\text { North, Moswansicut Pond) }\end{array}$ & 3.25 & M & 9 & $\mathrm{Y}$ & Continuous & Continuous \\
\hline 20 & 01115160 & $\begin{array}{l}\text { Unnamed Tributary } 1 \text { to Moswansicut } \\
\text { Reservoir (Blanchard Brook) }\end{array}$ & 1.18 & M & 9 & $\mathrm{~N}$ & None & None \\
\hline 21 & 01115165 & $\begin{array}{l}\text { Unnamed Tributary } 2 \text { to Moswansicut } \\
\text { Reservoir (Brook from Kimball Reservoir) }\end{array}$ & 0.29 & Q & 2 & $\mathrm{~N}$ & Estimated & None \\
\hline
\end{tabular}


Table 1. Providence Water Supply Board water-quality sampling stations, water-quality samples, and available streamflow and continuous-monitoring streamgages by tributary reservoir subbasin in the Scituate Reservoir drainage area, Rhode Island, 0ctober 1, 2013, to September 30, 2014.-Continued

[Alternate station names are given in parentheses for stations where different historical names were used for the same sampling location by the Providence Water Supply Board (PWSB). USGS, U.S. Geological Survey; mi², square miles; QW, water quality; Na, sodium; Cl, chloride; M, monthly; Q, quarterly; Y, yes; --, none]

\begin{tabular}{|c|c|c|c|c|c|c|c|c|}
\hline $\begin{array}{c}\text { PWSB } \\
\text { station } \\
\text { num- } \\
\text { ber }\end{array}$ & $\begin{array}{l}\text { USGS } \\
\text { station } \\
\text { number }\end{array}$ & Station name & $\begin{array}{l}\text { Drain- } \\
\text { age } \\
\text { area } \\
\left(\mathrm{mi}^{2}\right)\end{array}$ & $\begin{array}{l}\text { Frequen- } \\
\text { cy of } \mathrm{OW} \\
\text { sample } \\
\text { collec- } \\
\text { tion }\end{array}$ & $\begin{array}{c}\text { Number of } \\
\text { samples } \\
\text { collected } \\
\text { by Provi- } \\
\text { dence } \\
\text { Water }^{1}\end{array}$ & $\begin{array}{l}\text { Daily } \\
\text { estimat- } \\
\text { ed } \mathrm{Na} \\
\text { and } \mathrm{Cl} \\
\text { loads }\end{array}$ & $\begin{array}{l}\text { Streamflow } \\
\text { availability }\end{array}$ & $\begin{array}{c}\text { Specific } \\
\text { conduc- } \\
\text { tance } \\
\text { availability }\end{array}$ \\
\hline \multicolumn{9}{|c|}{ Moswansicut Reservoir subbasin-Continued } \\
\hline 22 & 01115167 & $\begin{array}{l}\text { Moswansicut Reservoir (Moswansicut Stream } \\
\text { South) }\end{array}$ & 0.22 & $\mathrm{M}$ & 8 & $\mathrm{~N}$ & None & None \\
\hline 34 & 01115164 & Kimball Stream & 0.27 & $\mathrm{Q}$ & 3 & $\mathrm{~N}$ & None & None \\
\hline \multicolumn{9}{|c|}{ Ponaganset Reservoir subbasin } \\
\hline 23 & 011151843 & Ponaganset Reservoir & 1.92 & M & 6 & $\mathrm{~N}$ & None & None \\
\hline \multicolumn{9}{|c|}{ Regulating Reservoir subbasin } \\
\hline 13 & 01115176 & Regulating Reservoir & 22.1 & $\mathrm{M}$ & 9 & $\mathrm{~N}$ & None & None \\
\hline 14 & 01115110 & Huntinghouse Brook & 6.23 & M & 6 & $\mathrm{Y}$ & Continuous & Continuous \\
\hline 15 & 01115114 & Rush Brook & 4.70 & M & 8 & $\mathrm{Y}$ & Continuous & Continuous \\
\hline 16 & 01115098 & Peeptoad Brook (Harrisdale Brook) & 4.96 & M & 12 & $\mathrm{Y}$ & Continuous & Continuous \\
\hline 17 & 01115119 & Dexter Pond (Paine Pond) & 0.22 & Q & 1 & $\mathrm{~N}$ & None & None \\
\hline 18 & 01115120 & $\begin{array}{l}\text { Unnamed Tributary to Regulating Reservoir } \\
\text { (Unnamed Brook A) }\end{array}$ & 0.28 & Q & 1 & $\mathrm{Y}$ & Continuous & Continuous \\
\hline \multicolumn{9}{|c|}{ Westconnaug Reservoir subbasin } \\
\hline 10 & 01115274 & Westconnaug Brook & 1.48 & $\mathrm{M}$ & 6 & $\mathrm{~N}$ & Estimated & None \\
\hline 11 & 01115273 & $\begin{array}{l}\text { Unnamed Tributary to Westconnaug Reservoir } \\
\text { (Unnamed Brook south of Westconnaug } \\
\text { Reservoir) }\end{array}$ & 0.72 & Q & 2 & $\mathrm{~N}$ & Estimated & None \\
\hline 12 & 011152745 & $\begin{array}{l}\text { Unnamed Tributary to Westconnaug Brook } \\
\text { (Unnamed Brook north of Westconnaug } \\
\text { reservoir) }\end{array}$ & 0.16 & Q & 2 & $\mathrm{~N}$ & None & None \\
\hline
\end{tabular}

${ }^{1}$ Not all samples were analyzed for all water-quality properties or constituents. 
Table 2. Measured or estimated annual mean streamflow for tributaries in the Scituate Reservoir drainage area, Rhode Island, October 1, 2013, through September 30, 2014.

[Alternate station names are given in parentheses for stations where different historical names were used for the same sampling location by the Providence Water Supply Board (PWSB); USGS, U.S. Geological Survey; $\mathrm{ft}^{3} / \mathrm{s}$, cubic feet per second; $\mathrm{ft}^{3} / \mathrm{s} / \mathrm{mi}^{2}$, cubic feet per second per square mile]

\begin{tabular}{|c|c|c|c|c|c|c|}
\hline $\begin{array}{l}\text { PWSB } \\
\text { station } \\
\text { number }\end{array}$ & $\begin{array}{l}\text { USGS } \\
\text { station } \\
\text { number }\end{array}$ & Station name & $\begin{array}{c}\text { Annual mean } \\
\text { streamflow } \\
\left(\mathrm{ft}^{3} / \mathrm{s}\right)\end{array}$ & $\begin{array}{c}\text { Upper } \\
\text { 90-percent } \\
\text { confidence } \\
\text { interval } \\
\left(\mathrm{ft}^{3} / \mathrm{s}\right)\end{array}$ & $\begin{array}{c}\text { Lower } \\
\text { 90-percent } \\
\text { confidence } \\
\text { interval } \\
\left(\mathrm{ft}^{3} / \mathrm{s}\right)\end{array}$ & $\begin{array}{c}\text { Annual mean } \\
\text { streamflow } \\
\left(\mathrm{ft}^{3} / \mathrm{s} / \mathrm{mi}^{2}\right)\end{array}$ \\
\hline \multicolumn{7}{|c|}{ Barden Reservoir subbasin } \\
\hline 24 & 01115190 & Dolly Cole Brook & 7.3 & 8.3 & 6.3 & 1.5 \\
\hline 26 & 01115185 & Windsor Brook & 6.1 & 25 & 1.5 & 1.4 \\
\hline 28 & 01115265 & Barden Reservoir (Hemlock Brook) & 14 & 17 & 12 & 1.7 \\
\hline 35 & 01115187 & Ponaganset River & 23 & 26 & 20 & 1.6 \\
\hline \multicolumn{7}{|c|}{ Direct Runoff subbasin } \\
\hline 1 & 01115180 & Brandy Brook & 1.8 & 3.3 & 1.0 & 1.2 \\
\hline 6 & 01115183 & Quonapaug Brook & 2.8 & 3.2 & 2.5 & 1.4 \\
\hline 7 & 01115297 & Wilbur Hollow Brook & 6.3 & 7.0 & 5.6 & 1.5 \\
\hline 8 & 01115276 & Westconnaug Brook (Westconnaug Reservoir) & 8.1 & 8.8 & 7.4 & 1.6 \\
\hline 9 & 01115275 & Bear Tree Brook & 1.1 & 1.2 & 0.98 & 1.7 \\
\hline 32 & 01115178 & $\begin{array}{l}\text { Unnamed Tributary } 1 \text { to Scituate Reservoir } \\
\text { (Pine Swamp Brook) }\end{array}$ & 0.46 & 0.92 & 0.23 & 1.0 \\
\hline 33 & 01115182 & $\begin{array}{l}\text { Unnamed Tributary } 3 \text { to Scituate Reservoir } \\
\text { (Hall's Estate Brook) }\end{array}$ & 0.35 & 0.99 & 0.13 & 1.3 \\
\hline \multicolumn{7}{|c|}{ Moswansicut Reservoir subbasin } \\
\hline 15 & 01115115 & Rush Brook & 7.2 & 8.4 & 6.0 & 1.5 \\
\hline 16 & 01115098 & Peeptoad Brook (Harrisdale Brook) & 7.5 & 8.7 & 6.3 & 1.5 \\
\hline 18 & 01115120 & $\begin{array}{l}\text { Unnamed Tributary to Regulating Reservoir } \\
\text { (Unnamed Brook A) }\end{array}$ & 0.37 & 0.47 & 0.27 & 1.3 \\
\hline \multicolumn{7}{|c|}{ Westconnaug Reservoir subbasin } \\
\hline 10 & 01115274 & Westconnaug Brook & 1.6 & 2.9 & 0.92 & 1.1 \\
\hline 11 & 01115273 & $\begin{array}{l}\text { Unnamed Tributary to Westconnaug Reservoir } \\
\text { (Unnamed Brook South of Westconnaug Reservoir) }\end{array}$ & 0.95 & 1.6 & 0.56 & 1.3 \\
\hline
\end{tabular}


analyzed the specific conductance data. Specific conductance was measured by the USGS at 10- or 15-minute intervals at the 14 continuous-record streamgages (fig. 1). Measurements were made by using an instream probe and standard USGS methods for continuous streamwater-quality monitoring (Wagner and others, 2006).

Concentrations of sodium and chloride were estimated from continuous measurements of specific conductance by using equations that were developed by the USGS to relate specific conductance to concentrations of sodium and chloride (equations 1 and 2). These regression equations were developed by using the MOVE.1 method (also known as the line of organic correlation; Helsel and Hirsch, 2002) on the basis of concurrent measurements of specific conductance ${ }^{3}$ along with sodium ${ }^{4}$ and chloride ${ }^{5}$ concentrations measured in water-quality samples collected by the USGS from tributaries in the Scituate Reservoir drainage area (U.S. Geological Survey, 2001):

$$
\begin{gathered}
C_{C l}=\left(S p c^{m}\right) \times b \text { and } \\
C_{N a}=\left(S p c^{m}\right) \times b,
\end{gathered}
$$

where

$$
\begin{aligned}
& C_{C l} \text { is the chloride concentration, in milligrams } \\
& \text { per liter; } \\
& C_{N a} \text { is the sodium concentration, in milligrams per } \\
& \text { liter; } \\
& \text { Spc is the specific conductance, in microsiemens } \\
& \text { per centimeter; } \\
& m \quad \text { is the slope from the MOVE. } 1 \text { analysis } \\
& \text { (table 3); and } \\
& b \quad \text { is the intercept from the MOVE. } 1 \text { analysis } \\
& \text { (table 3). }
\end{aligned}
$$

MOVE.1 was chosen for regression analysis to maintain variance (Hirsch and Gilroy, 1984). Some missing values of specific conductance were estimated. In these cases, values of specific conductance were estimated by proportional distribution between recorded values.

\section{Data Collected by the Providence Water Supply Board}

Water-quality samples were collected at fixed stations on 37 tributaries by the PWSB. Sampling was conducted monthly at 19 stations and quarterly at another 18 stations (table 1) during WY 2014. Water-quality samples were not collected during specific weather conditions; instead, a strictly periodic water-quality sampling schedule was followed so

\footnotetext{
${ }^{3}$ Specific conductance parameter code 90095

${ }^{4}$ Sodium parameter code 00930.
}

${ }^{5}$ Chloride parameter code 00940. that water-quality samples would be representative of various weather conditions. However, sometimes samples could not be collected because tributaries at the sampling stations were dry or frozen. When possible, water-quality samples were collected by dipping the sample bottle into the tributary at the center of flow (Richard Blodgett, PWSB, written commun., 2005). Samples were transported on ice to the PWSB waterquality laboratory at the P.J. Holton Water Purification Plant in Scituate. Water-quality properties and constituent concentrations were measured by using unfiltered water samples. These water-quality properties included $\mathrm{pH}$, temperature, acidity, alkalinity, color, turbidity, and concentrations of chloride, nitrite, nitrate, orthophosphate, and bacteria (Escherichia coli [E. coli] and total coliform). More information on samplecollection, analytical, and quality-control procedures can be found in the Providence Water Supply Board Quality Assurance Program Manual (Providence Water Supply Board Water Quality Laboratory, 2012).

Water-quality samples were collected by the PWSB during a wide range of flow conditions. The daily mean flowduration curve for Wilbur Hollow Brook at Old Plainfield Pike near Clayville (USGS streamgage 01115297) for WY 2014 is shown in figure 2 . The curve represents the percentage of time that each flow was equaled or exceeded at this station. The flows at this station on days when water-quality samples were collected are represented by the plotted points superimposed on the curve. Samples were collected at flow durations ranging from the 1st percentile to the 91 st percentile; this range indicates that the water-quality samples collected in WY 2014 represented a wide range of flow conditions during that water year.

\section{Estimating Daily, Monthly, and Annual Loads and Yields}

Daily, monthly, and annual sodium and chloride loads in kilograms were estimated for all streamgages for which continuous-streamflow and specific-conductance data were available for WY 2014. Daily flow-weighted concentrations of sodium and chloride were calculated by multiplying instantaneous flows by concurrent concentrations of sodium and chloride (estimated from measurements of specific conductance) for each day and dividing by the total flow for that day. Daily sodium and chloride loads were estimated by multiplying daily flow-weighted concentrations of sodium and chloride in milligrams per liter by daily discharge (in liters per day). Daily data were summed to estimate monthly or annual loads.

Daily loads of water-quality constituents (in samples collected by the PWSB) were calculated for all sampling dates during WY 2014 (table 4, at back of report) for which periodic- or continuous-streamflow data were available (table 1). These loads were calculated by multiplying constituent concentrations in milligrams or colony forming units (CFU) per liter in single samples by the daily discharge (in liters per 
Table 3. Regression equation coefficients used to estimate concentrations of chloride and sodium from values of specific conductance for each U.S. Geological Survey monitoring station in the Scituate Reservoir drainage area, Rhode Island, 0ctober 1, 2013, through September 30, 2014.

[Parameter codes: specific conductance, 90095; chloride, 00940; sodium, 00930. PWSB, Providence Water Supply Board; USGS, U.S. Geological Survey]

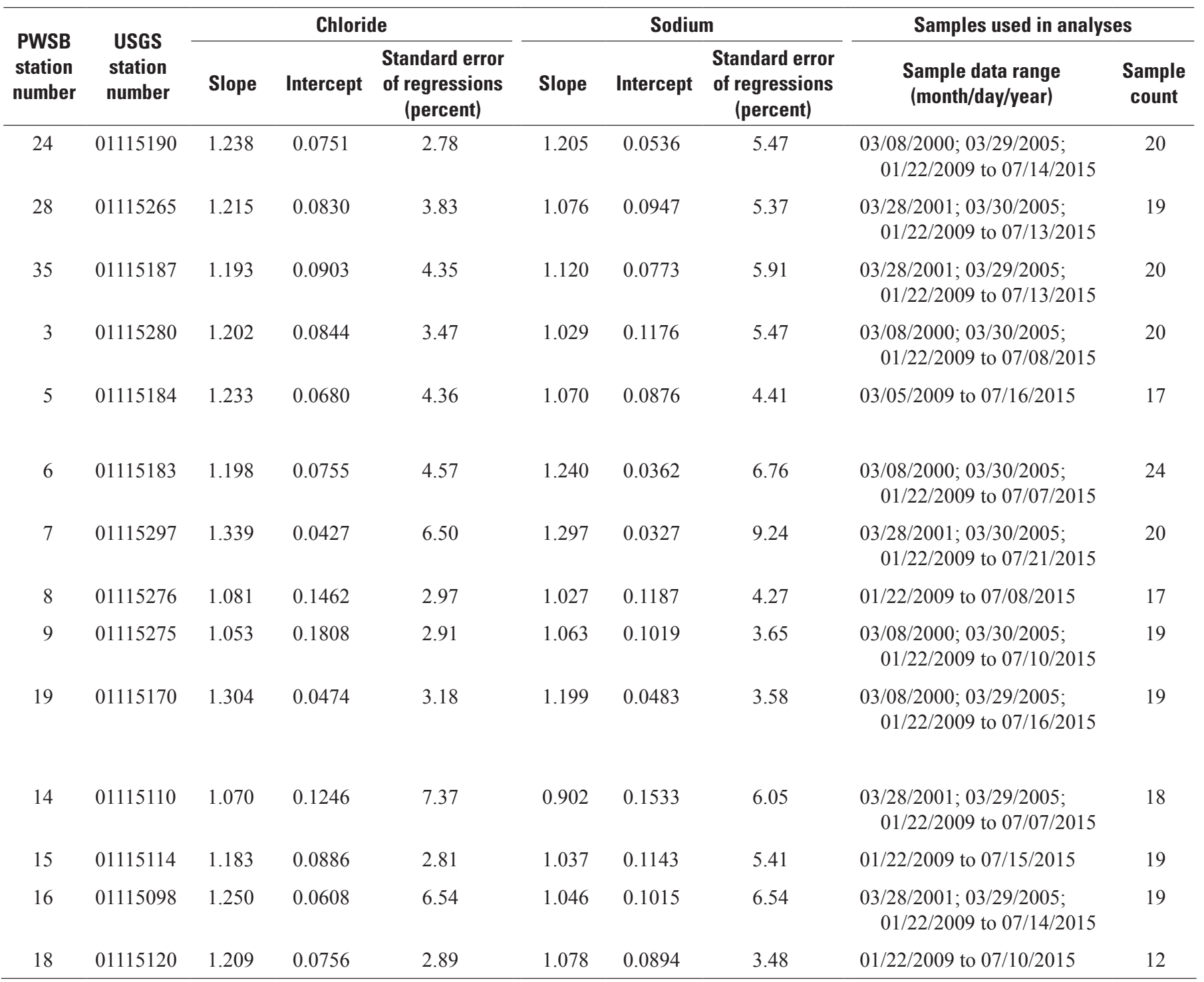




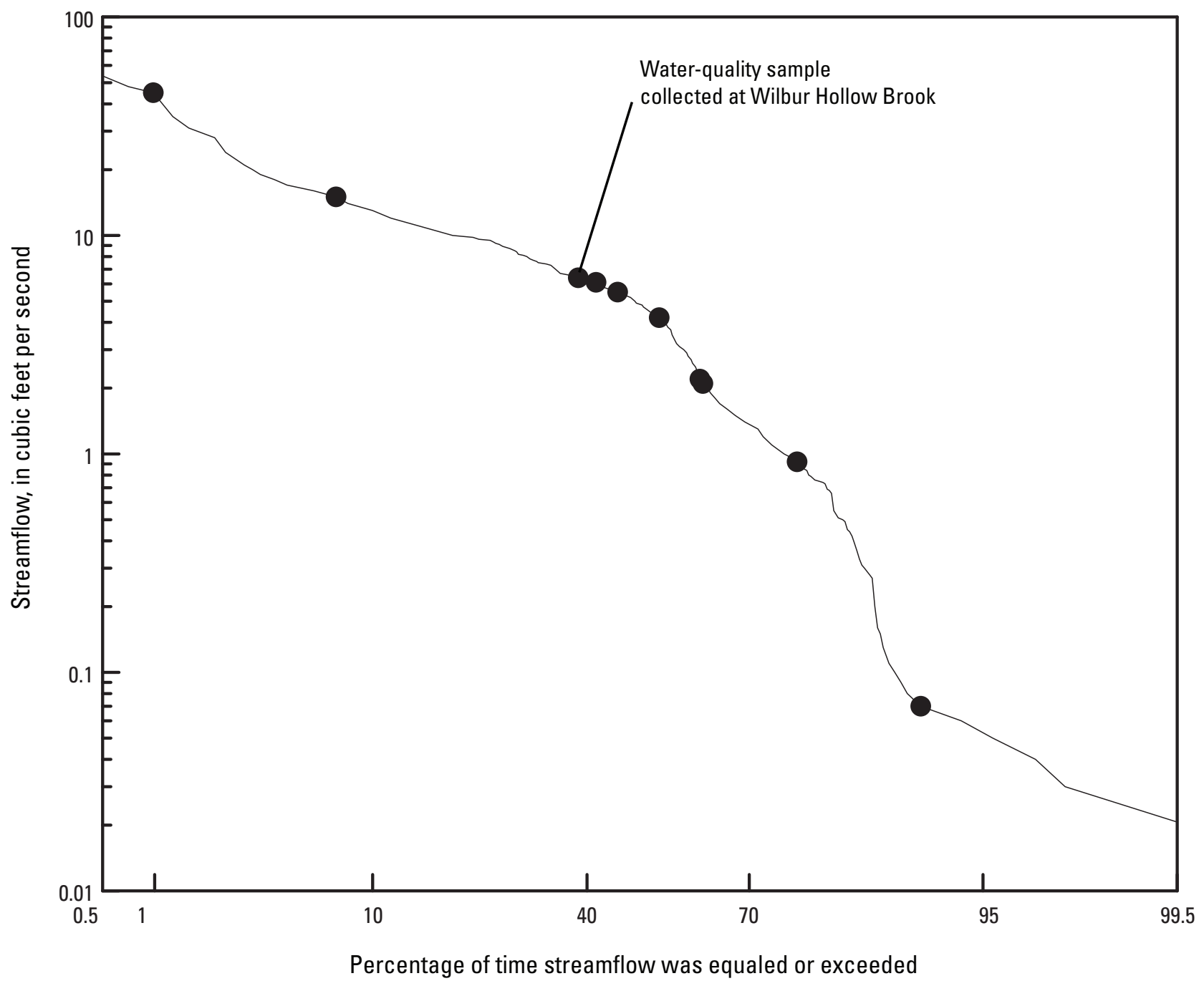

Figure 2. Flow-duration curve and streamflow on the dates (represented by points) when water-quality samples were collected for the U.S. Geological Survey continuous-record streamgage on Wilbur Hollow Brook at Old Plainfield Pike near Clayville (01115297), Rhode Island, water year 2014. 
day) for the day on which each sample was collected. The flows, which in some cases were estimates, were assumed to be representative of the flow at the time of the sample collection. Loads in grams or kilograms (or millions of CFUs for bacteria) per day and yields in grams or kilograms (or millions of CFUs for bacteria) per day per square mile were calculated for bacteria, chloride, nitrite, nitrate, and orthophosphate. Censored data (or concentrations reported as less than method detection limits) were replaced with concentrations equal to one-half the method detection limit.

\section{Streamflow}

Monitoring streamflow is necessary to measure the volume of water and estimate constituent loads to the Scituate Reservoir. The Ponaganset River is the largest monitored tributary to the Scituate Reservoir. Mean annual streamflow at the streamgage on the Ponaganset River (PWSB station 35; USGS streamgage 01115187) for the entire period of its operation (mean of the annual mean streamflows for the period of record, WY 1994-2013) prior to WY 2014 was about 29 cubic feet per second ( $\left.\mathrm{ft}^{3} / \mathrm{s}\right)$ (http://waterdata.usgs. gov/nwis). During WY 2014, annual mean streamflow was $23 \mathrm{ft}^{3} / \mathrm{s}$, and daily mean streamflows for many months were less than the median daily mean streamflows for the period of record (fig. 3). Mean annual streamflow in Peeptoad Brook (PWSB station 16, streamgage 01115098), the other longterm continuous-record streamgage in the Scituate Reservoir drainage area, for its period of record (WY 1994-2013) prior to WY 2014 was about $11 \mathrm{ft}^{3} / \mathrm{s}$ (http://waterdata.usgs.gov/ nwis). Annual mean streamflow in Peeptoad Brook during WY 2014 was $7.5 \mathrm{ft}^{3} / \mathrm{s}$ (table 2).

\section{Water Quality and Constituent Loads and Yields}

Water-quality conditions in the Scituate Reservoir drainage area are described by summary statistics for water-quality properties, constituent concentrations, and estimated constituent loads and yields. Loads and yields characterize the rates at which masses of constituents are transferred to the reservoir by tributaries. In the case of loads, tributaries with high flows tend to have high loads because the greater volume of water can carry more of the constituent to the reservoir per unit time. Yields represent the constituent load per unit of drainage area and are calculated by dividing the load estimated for a streamgage by the drainage area to the monitoring station. Yields are useful for comparison among streamgages that have different drainage areas because the effects of basin size and therefore total streamflow volume are attenuated. Yields also are useful for examining potential differences among basin properties that may contribute to reservoir quality.

Summary statistics include means and medians. For some purposes, median values are more appropriate because they are less likely to be affected by high or low concentrations (or outliers). Medians are especially important to use for summarizing a relatively limited number of values. In contrast, continuously monitored streamflow and sodium and chloride loads (estimated from measurements of specific conductance), which include a large number of values, are better summarized in terms of means because a large dataset is more resistant to the effects of outliers. Mean values also are particularly appropriate for characterizing loads because outlier values, which typically represent large flows, are important to include in estimates of constituent masses delivered to receiving waters.

Uncertainties associated with measuring streamflow and specific conductance and with sodium and chloride sample collection, preservation, and analysis produce uncertainties in load and yield estimates. The load and yield estimates presented in the text and tables are the most likely values for sodium and chloride coming from tributaries or their drainage basins. It may be best to discuss loads and yields in terms of a range within which the true values lie; however, the most probable values of loads and yields are presented for ease of discussion and presentation. The range within which the true values lie depends on the uncertainties in individual measurements of streamflow and concentration, which are difficult to quantify with available information. The uncertainties associated with estimating streamflow are commonly assumed to affect load and yield calculations more than the errors associated with measuring specific conductance and (or) chemical analysis. The most probable values of loads and yields presented in the tables and text are sufficient for planning-level analysis of water quality in tributaries and their drainage basins.

\section{Sodium and Chloride Loads and Yields Estimated from Specific-Conductance Monitoring Data}

Sodium and chloride are constituents of special concern in the Scituate Reservoir drainage area; they are major constituents of road salt used for deicing, and several major roadways cross the drainage basin. State Routes 12 and 14 cut across the main body of the reservoir, and State Route 116 parallels the eastern limb (fig. 1). Nimiroski and Waldron (2002) indicated that tributaries in basins with state-maintained roads had substantially higher concentrations of sodium and chloride than tributaries in basins with low road density, presumably because of deicing activities. In addition, sodium is a constituent of potential concern for human health; some persons on restricted diets might need to limit intake of sodium. 


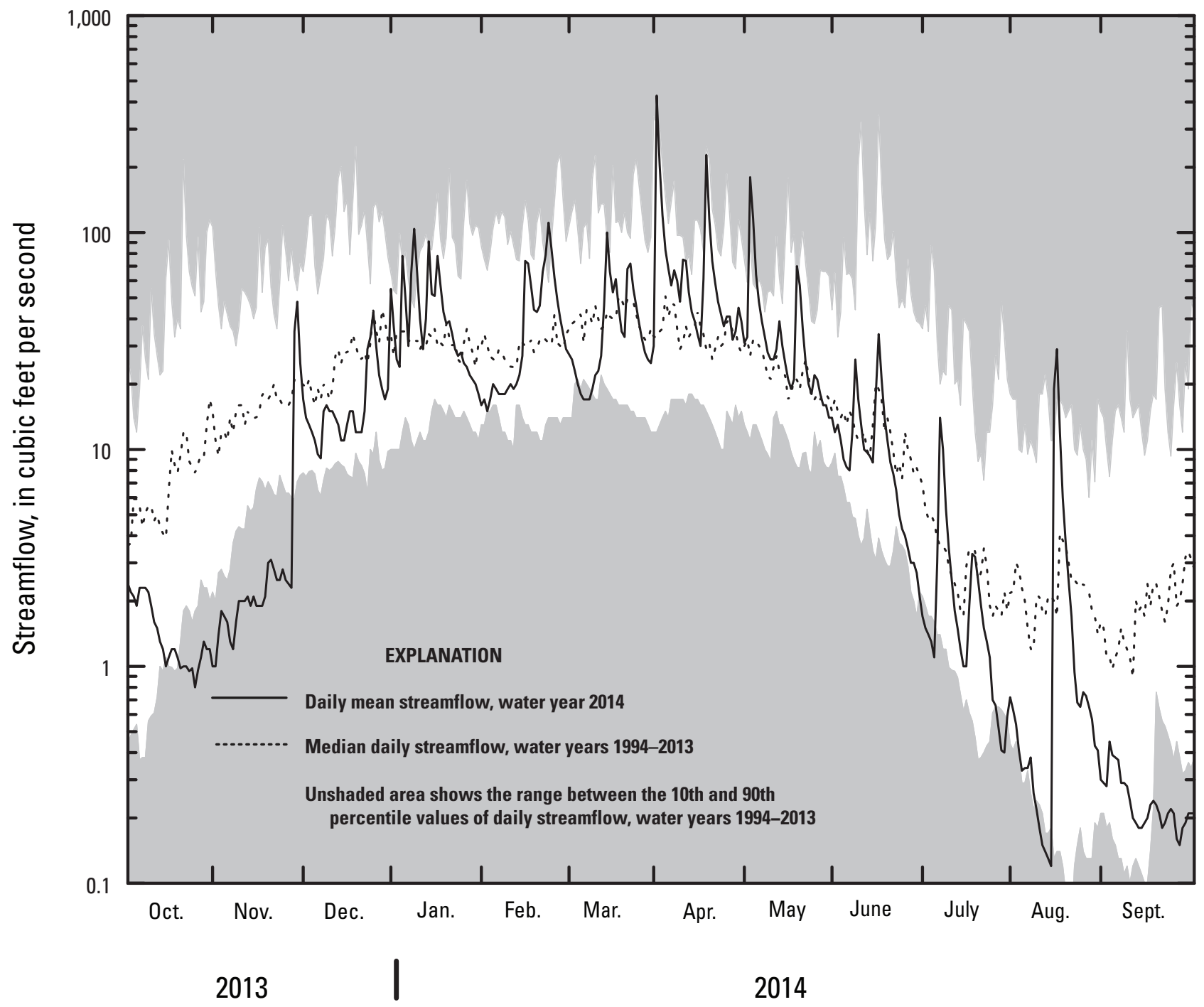

Figure 3. Measured daily mean streamflow for October 1, 2013, through September 30, 2014, and the 10th percentile, median, and 90th percentile values of daily streamflow for October 1, 1994, through September 30, 2013, for the U.S. Geological Survey continuous-record streamgage on the Ponaganset River at South Foster (01115187) in the Scituate Reservoir drainage area, Rhode Island. 
Estimated monthly mean ${ }^{6}$ sodium concentrations in tributaries of the Scituate Reservoir drainage area ranged from 4.9 to 50.1 milligrams per liter $(\mathrm{mg} / \mathrm{L})$, and estimated monthly mean chloride concentrations ranged from 7.5 to $83.9 \mathrm{mg} / \mathrm{L}$ (table 5 ). The highest monthly mean concentrations of sodium and chloride were measured in Bear Tree Brook (PWSB station 9) in September 2013 (50.1 and $83.9 \mathrm{mg} / \mathrm{L}$, respectively; table 5). The highest annual mean ${ }^{7}$ concentrations of sodium and chloride also were measured in Bear Tree Brook (29.4 and $49.4 \mathrm{mg} / \mathrm{L}$, respectively; table 6 ). These high concentrations are the result of residual sodium and chloride leaching from a formerly uncovered salt storage pile to groundwater (Nimiroski and Waldron, 2002) and relatively small surfacewater flows.

During WY 2014, the Scituate Reservoir received about 1,200,000 kilograms ( $\mathrm{kg}$ ) (about 1,300 short tons) of sodium and 2,100,000 kg (about 2,300 short tons) of chloride from tributaries that are equipped with instrumentation capable of continuously monitoring specific conductance. The highest sodium and chloride loads in the drainage area during WY 2014 (260,000 and 420,000 kg, respectively) were measured at the Ponaganset River station (PWSB station 35; table 6). Monthly estimated sodium and chloride loads were highest in the months of January, February, March, and April (table 7). During these 4 months, the sum of the monthly sodium and chloride loads at each station accounted for 68 percent of the annual load for the monitored area in the Scituate Reservoir drainage area. The highest annual sodium and chloride yields were 45,000 and 75,000 kilograms per square mile, respectively, measured at Bear Tree Brook (PWSB station 9; table 6). Annual loads of sodium and chloride tended to be less than the median annual loads for WY 2009-13, except at the stations on Westconnaug Brook (PWSB station 8) and Rush Brook (PWSB station 15), which were greater than the median annual loads (fig. 4).

\section{Physical and Chemical Properties and Daily Loads and Yields Estimated from Data Collected by the Providence Water Supply Board}

\section{Physical and Chemical Properties}

Physical and chemical properties including $\mathrm{pH}$, turbidity, alkalinity, specific conductance, and color were routinely measured to characterize water quality in each subbasin (table 8). Specifically, $\mathrm{pH}$ is a measure of the acidity of the water, color can be an indirect measure of the amount of organic carbon dissolved in the water column, turbidity is an indirect measure

\footnotetext{
${ }^{6}$ Monthly mean concentrations were calculated by dividing the total monthly load by the total discharge for the month.

${ }^{7}$ Annual mean concentrations were calculated by dividing the total annual load by the total discharge for the year.
}

of suspended particles, and alkalinity is a measure of the acidneutralizing capacity of water.

The median $\mathrm{pH}$ in tributaries in the Scituate Reservoir drainage area ranged from 5.6 to 6.9 ; the median of the medians for all stations was 6.3. Median values of color ranged from 12 to 150 platinum cobalt units (PCU); the median for all stations was 39 PCU. Median values of turbidity ranged from 0.27 to 3.3 nephelometric turbidity units (NTU); the median for all stations was 0.61 NTU. Median alkalinity values in tributaries were low, ranging from 2.5 to $17 \mathrm{mg} / \mathrm{L}$ as $\mathrm{CaCO}_{3}$; the median for all stations was $6.1 \mathrm{mg} / \mathrm{L}$ as $\mathrm{CaCO}_{3}$ (table 8).

\section{Constituent Concentrations and Daily Loads and Yields}

Fecal indicator bacteria, chloride, and nutrients such as nitrogen $(\mathrm{N})$ and phosphorus are commonly detected in natural water; at elevated concentrations, these constituents can render water unfit for the intended use. Fecal indicator bacteria, which are found in the intestines of warm-blooded animals, may indicate impairment from sewage contamination or from livestock or wildlife that defecate in or near the stream margin. Chloride originates in tributary streamwater from precipitation, weathering, or human activities such as waste disposal, use of septic systems, and road deicing. Sources of nutrients in tributary streamwater include atmospheric deposition, leaching of naturally occurring organic material, discharge of groundwater that is enriched with nutrients from septic-system leachate, and runoff contaminated with fertilizer or animal waste. The ultimate intended use of water in the tributaries is drinking water, which must meet specific water-quality standards. For this reason, the PWSB and the USGS closely monitor concentrations of these constituents in tributaries. Median concentrations, loads, and yields of water-quality constituents are given in tables 8 and 9 .

\section{Bacteria}

Median concentrations of total coliform bacteria were above the detection limit (10 colony forming units per 100 milliliters [CFU/100 mL]) at all sites (table 8); median concentrations of $E$. coli were equal to or greater than the detection limit $(10 \mathrm{CFU} / 100 \mathrm{~mL})$ at 31 of the 37 sites. Total coliform bacteria concentrations were greater than $E$. coli concentrations (as expected because total coliform is more inclusive); the medians of median concentrations for all sites in the drainage area were $320 \mathrm{CFU} / 100 \mathrm{~mL}$ for total coliform bacteria and $20 \mathrm{CFU} / 100 \mathrm{~mL}$ for E. coli. The median concentration of total coliform bacteria was highest at Kent Brook (PWSB station 4; table 8) at 3,700 CFU/100 mL. The median concentration of $E$. coli was highest at Unnamed Tributary \#4 to Scituate Reservoir (PWSB station 30; table 8) at $350 \mathrm{CFU} / 100 \mathrm{~mL}$. 


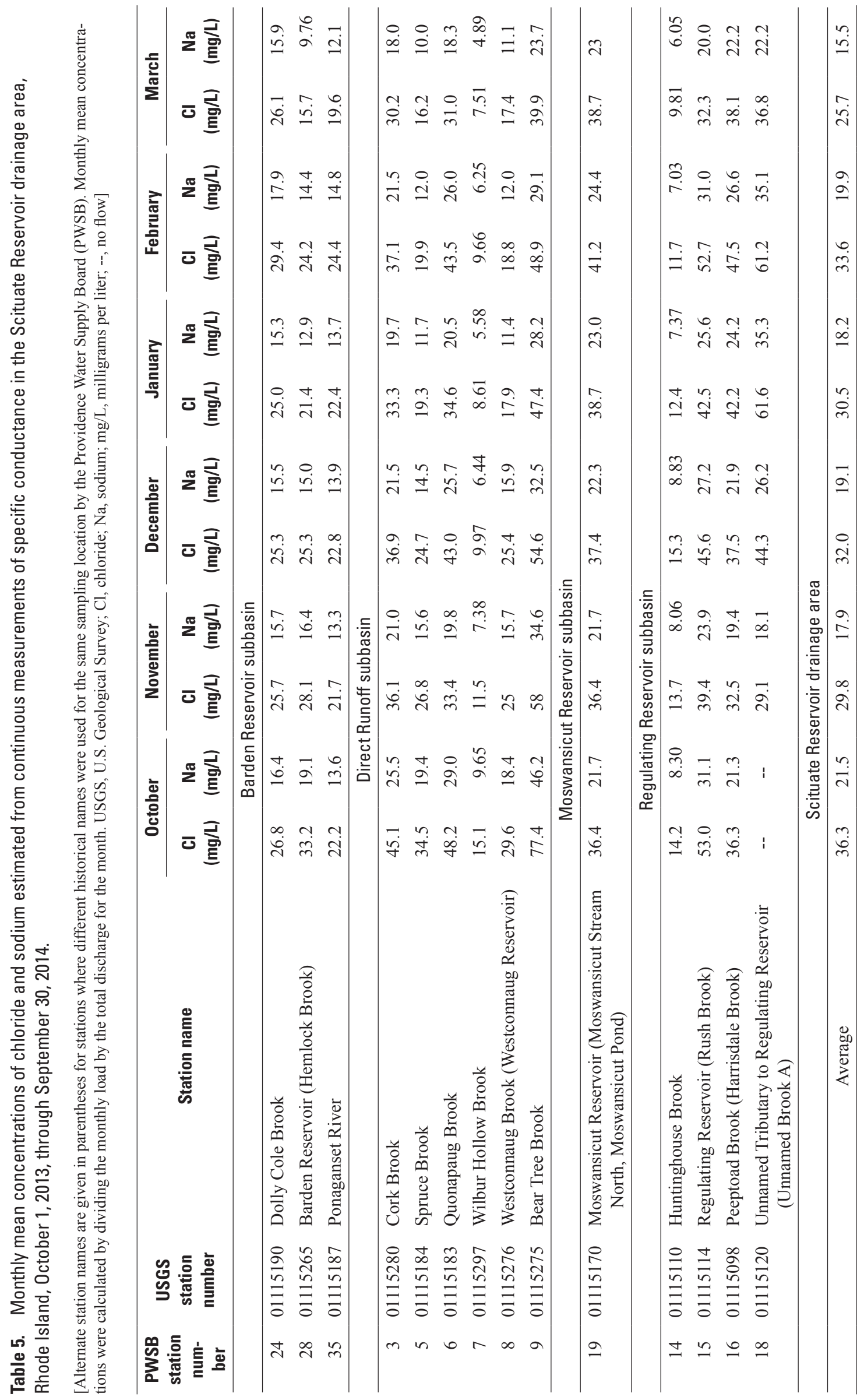




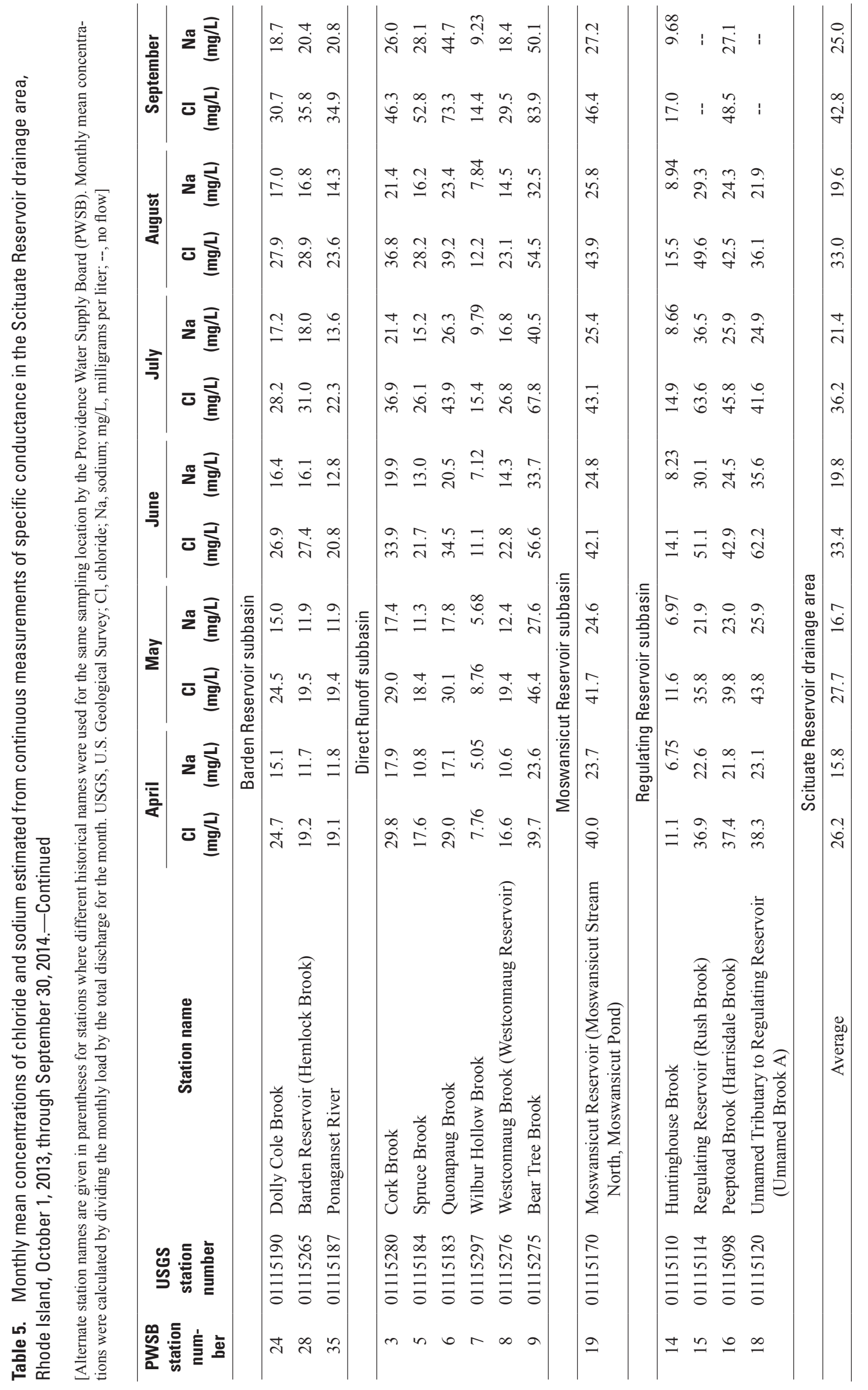


Table 6. Annual mean chloride and sodium concentrations, loads, and yields by sampling station in the Scituate Reservoir drainage area, Rhode Island, October 1, 2013, through September 30, 2014.

[Alternate station names are given in parentheses for stations where different historical names were used for the same sampling location by the Providence Water Supply Board (PWSB). Annual mean concentrations were calculated by dividing the annual load by the total discharge for the year; annual mean yields were calculated by dividing the sum of individual loads by the sum of the drainage area. USGS, U.S. Geological Survey; $\mathrm{mg} / \mathrm{L}, \mathrm{milligrams} \mathrm{per} \mathrm{liter;} \mathrm{kg} / \mathrm{yr}$, kilograms per year; $\mathrm{kg} / \mathrm{yr} / \mathrm{mi}^{2}$, kilograms per year per square mile; $\mathrm{Cl}$, chloride; $\mathrm{Na}$, sodium]

\begin{tabular}{|c|c|c|c|c|c|c|c|c|}
\hline \multirow{2}{*}{$\begin{array}{l}\text { PWSB } \\
\text { station } \\
\text { number }\end{array}$} & \multirow{2}{*}{$\begin{array}{c}\text { USGS } \\
\text { station } \\
\text { number }\end{array}$} & \multirow[b]{2}{*}{ Station name } & \multicolumn{2}{|c|}{ Concentration } & \multicolumn{2}{|c|}{ Load } & \multicolumn{2}{|c|}{ Yield } \\
\hline & & & $\begin{array}{c}\mathrm{Cl} \\
(\mathrm{mg} / \mathrm{L})\end{array}$ & $\begin{array}{c}\mathrm{Na} \\
(\mathrm{mg} / \mathrm{L})\end{array}$ & $\underset{(\mathrm{kg} / \mathrm{yr})}{\mathrm{Cl}}$ & $\underset{(\mathrm{kg} / \mathrm{yr})}{\mathrm{Na}}$ & $\begin{array}{c}\mathrm{Cl} \\
\left(\mathrm{kg} / \mathrm{yr} / \mathrm{mi}^{2}\right)\end{array}$ & $\begin{array}{c}\mathrm{Na} \\
\left(\mathrm{kg} / \mathrm{yr} / \mathrm{mi}^{2}\right)\end{array}$ \\
\hline 24 & 01115190 & Dolly Cole Brook & 25.9 & 15.8 & 170,000 & 100,000 & 34,000 & 21,000 \\
\hline 28 & 01115265 & Barden Reservoir (Hemlock Brook) & 20.6 & 12.4 & 260,000 & 160,000 & 30,000 & 18,000 \\
\hline 3 & 01115280 & Cork Brook & 32.3 & 19.1 & 67,000 & 39,000 & 37,000 & 22,000 \\
\hline 5 & 01115184 & Spruce Brook & 19.3 & 11.7 & 31,000 & 19,000 & 25,000 & 15,000 \\
\hline 6 & 01115183 & Quonapaug Brook & 33.9 & 20.1 & 85,000 & 50,000 & 43,000 & 26,000 \\
\hline 7 & 01115297 & Wilbur Hollow Brook & 9.12 & 5.90 & 51,000 & 33,000 & 12,000 & 7,700 \\
\hline 19 & 01115170 & $\begin{array}{l}\text { Moswansicut Reservoir, (Moswansicut } \\
\text { Stream North, Moswansicut Pond) }\end{array}$ & 40.0 & 23.7 & 160,000 & 92,000 & 48,000 & 28,000 \\
\hline \multicolumn{9}{|c|}{ Regulating Reservoir subbasin } \\
\hline 14 & 01115110 & Huntinghouse Brook & 11.6 & 6.95 & 95,000 & 57,000 & 15,000 & 9,100 \\
\hline 15 & 01115114 & Rush Brook & 40.6 & 24.5 & 260,000 & 160,000 & 55,000 & 33,000 \\
\hline 16 & 01115098 & Peeptoad Brook (Harrisdale Brook) & 39.3 & 22.7 & 260,000 & 150,000 & 53,000 & 30,000 \\
\hline 18 & 01115120 & $\begin{array}{l}\text { Unnamed Tributary to Regulating Reservoir } \\
\text { (Unnamed Brook A) }\end{array}$ & 45.4 & 26.8 & 15,000 & 8,900 & 54,000 & 32,000 \\
\hline \multicolumn{9}{|c|}{ Scituate Reservoir drainage area } \\
\hline
\end{tabular}




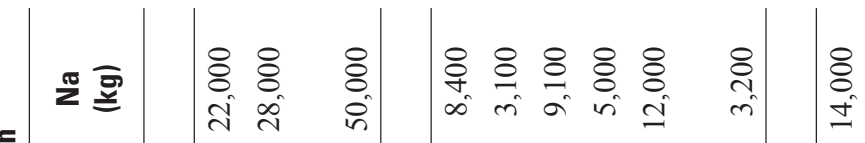

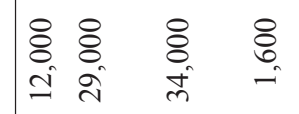

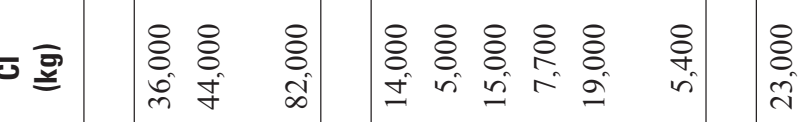

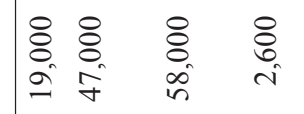

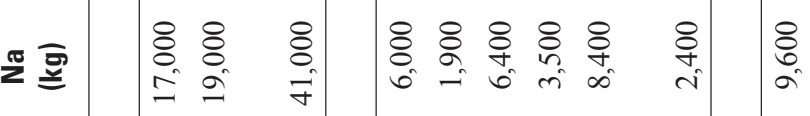

U

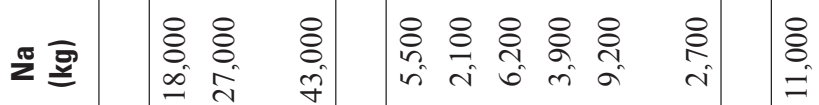

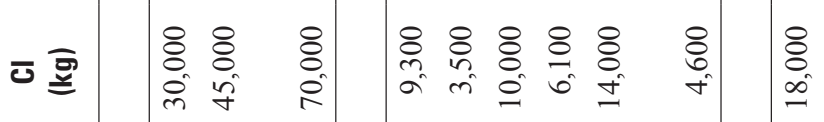

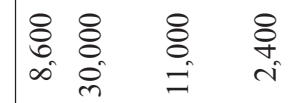

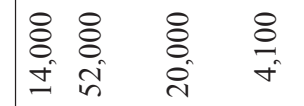

జ

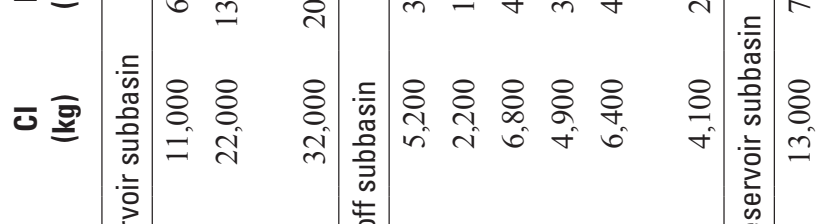

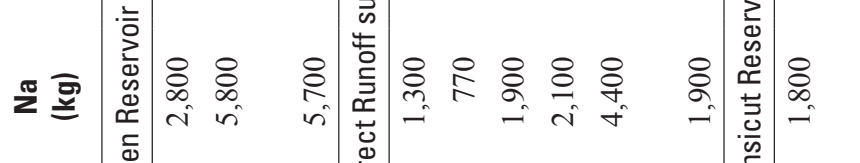

㐫

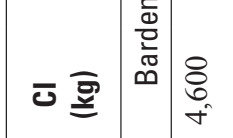

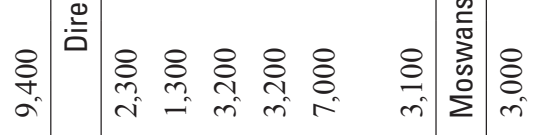

$\begin{array}{cccc}8 & 8 & 8 & 8 \\ i & 0 & 0 & 0 \\ \infty & i & 1 & -1\end{array}$

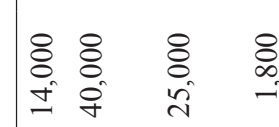

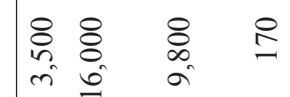

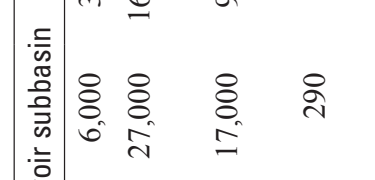

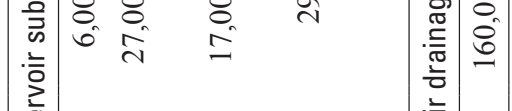

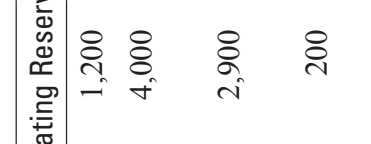

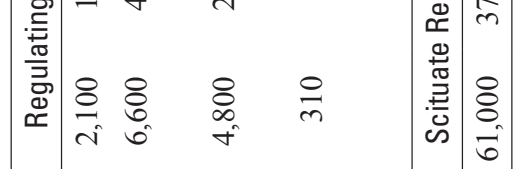

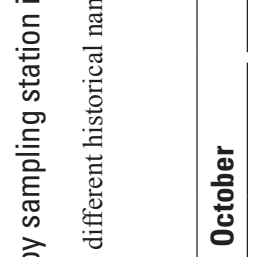

«

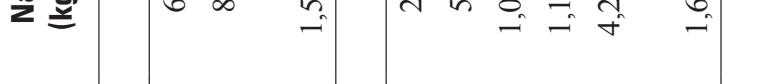

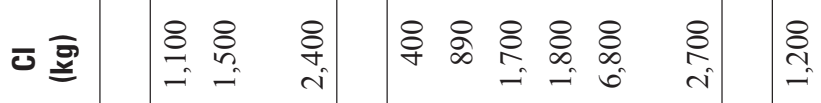

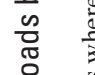

紊

s

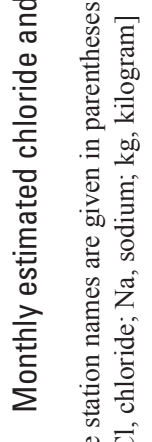

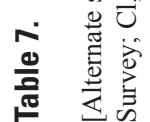

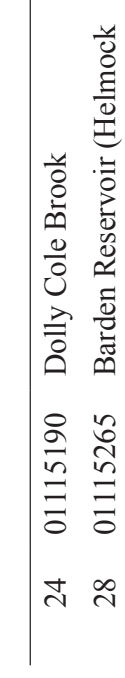

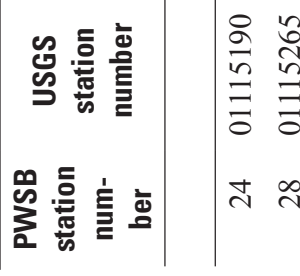

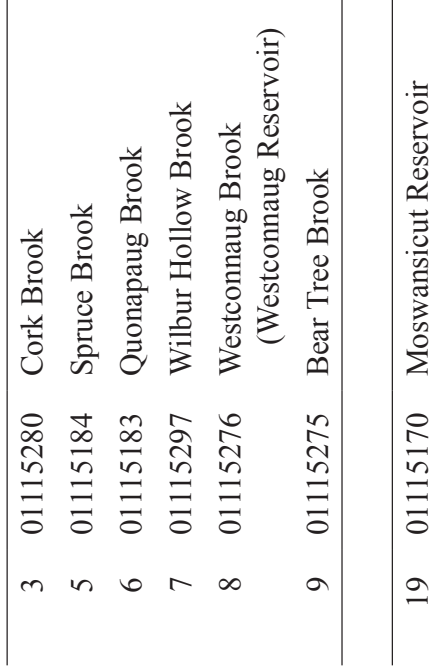

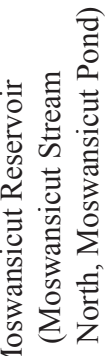

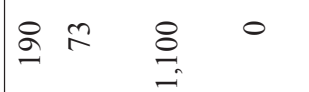

$\$$
$\vdots$
$\dot{\Xi}$

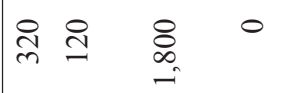

$\delta$
$\delta$
$i$
$i$
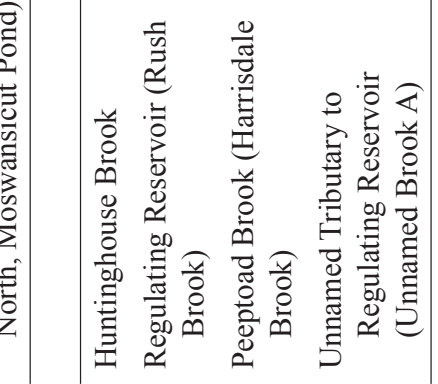

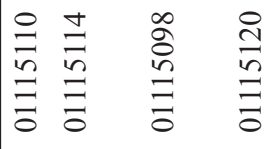

ป 


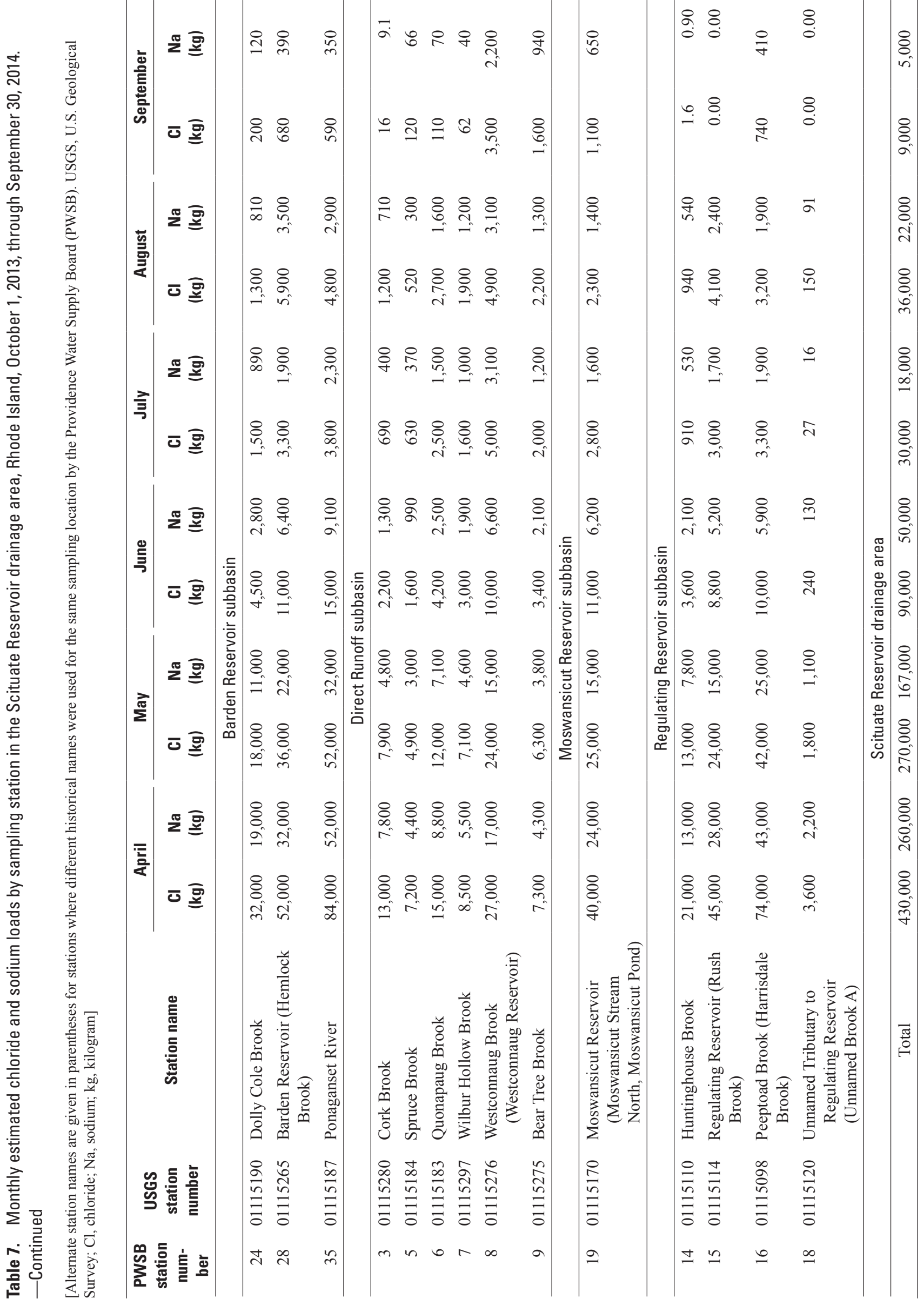




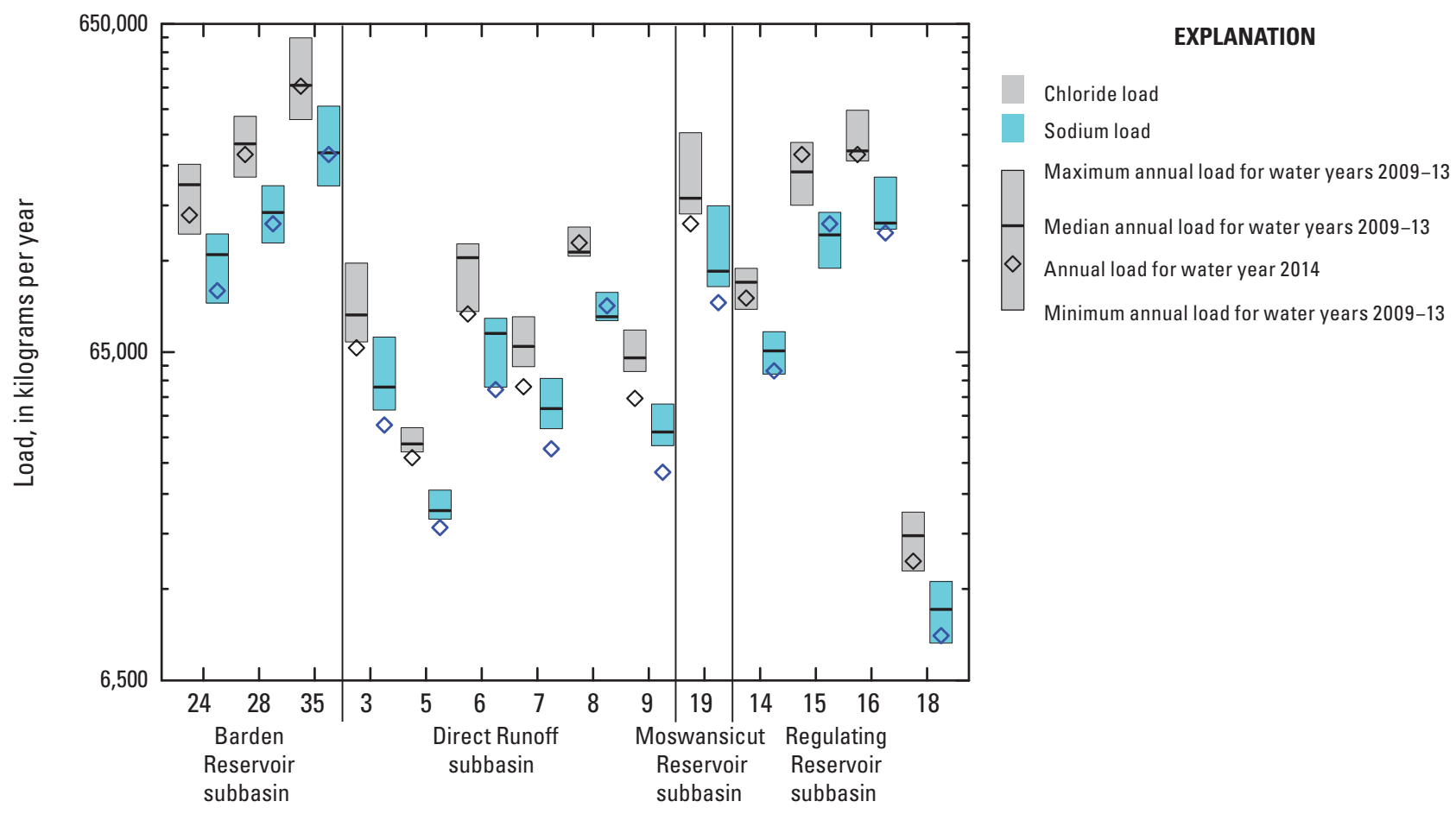

Providence Water Supply Board station number

Figure 4. Annual loads of chloride and sodium estimated from continuous measurements of streamflow and specific conductance for water year 2014 and associated minimum, maximum, and median annual loads for water years 2009-13 at 14 Providence Water Supply Board stations in the Scituate Reservoir drainage area, Rhode Island.

Median concentrations of fecal indicator bacteria were lowest at sampling stations Westconnaug Brook (PWSB station 8), Ponaganset Reservoir (PWSB station 23), Outflow from King Pond (PWSB station 36, and Fire Tower Stream (PWSB station 37). Median concentrations of E. coli were below detection limits at Shippee Brook (PWSB station 25), Ponaganset River (PWSB station 29), Spruce Brook (PWSB station 5), Westconnaug Brook (PWSB station 8), Fire Tower Stream (PWSB station 37), and Dexter Pond (PWSB station 17). Median daily loads and yields of total coliform bacteria and E. coli varied by more than two orders of magnitude; the highest median daily yield of total coliform bacteria (21,000 million colony forming units per day per square mile $\left[\mathrm{CFU} \times 10^{6} / \mathrm{d} / \mathrm{mi}^{2}\right]$ ) was at Bear Tree Brook (PWSB station 9; table 9), and the highest median daily yield of E. coli $\left(2,100 \mathrm{CFU} \times 10^{6} / \mathrm{d} / \mathrm{mi}^{2}\right)$ was at Wilbur Hollow Brook (PWSB station 7; table 9). Although relatively high for sampling stations in the Scituate Reservoir subbasin, median daily bacteria yields at Bear Tree Brook are low to moderate compared to yields of indicator bacteria in sewage-contaminated streamwater or streamwater affected by stormwater runoff in an urban environment (Breault and others, 2002). The median daily loads of total coliform bacteria for all subbasins in the Scituate Reservoir drainage area ranged from 850 to 120,000 million colony forming units per day $\left(\mathrm{CFU} \times 10^{6} / \mathrm{d}\right)$, and yields ranged from 2,900 to $21,000 \mathrm{CFU} \times 10^{6} / \mathrm{d} / \mathrm{mi}^{2} ; E$. coli loads ranged from 34 to $9,300 \mathrm{CFU} \times 10^{6} / \mathrm{d}$, and yields ranged from 120 to $2,100 \mathrm{CFU} \times 10^{6} / \mathrm{d} / \mathrm{mi}^{2}$ (table 9 ). At many stations, median daily loads for total coliform bacteria were substantially lower than in the previous water year, when the median daily loads of total coliform bacteria ranged from 440 to $200,000 \mathrm{CFU} \times 10^{6} / \mathrm{d}$. Median daily loads of E. coli also were less than loads for many stations in the previous water year, when loads of $E$. coli ranged from 100 to $14,000 \mathrm{CFU} \times 10^{6} / \mathrm{d}$ (Smith, 2015a).

\section{Chloride and Sodium}

The highest median chloride concentration $(94 \mathrm{mg} / \mathrm{L})$ was measured in the Direct Runoff subbasin at Toad Pond (PWSB station 31; table 8). Median daily chloride loads and yields estimated from samples collected by the PWSB varied among monitoring stations in the drainage area (table 9); the median daily chloride yield for monitored areas within the 


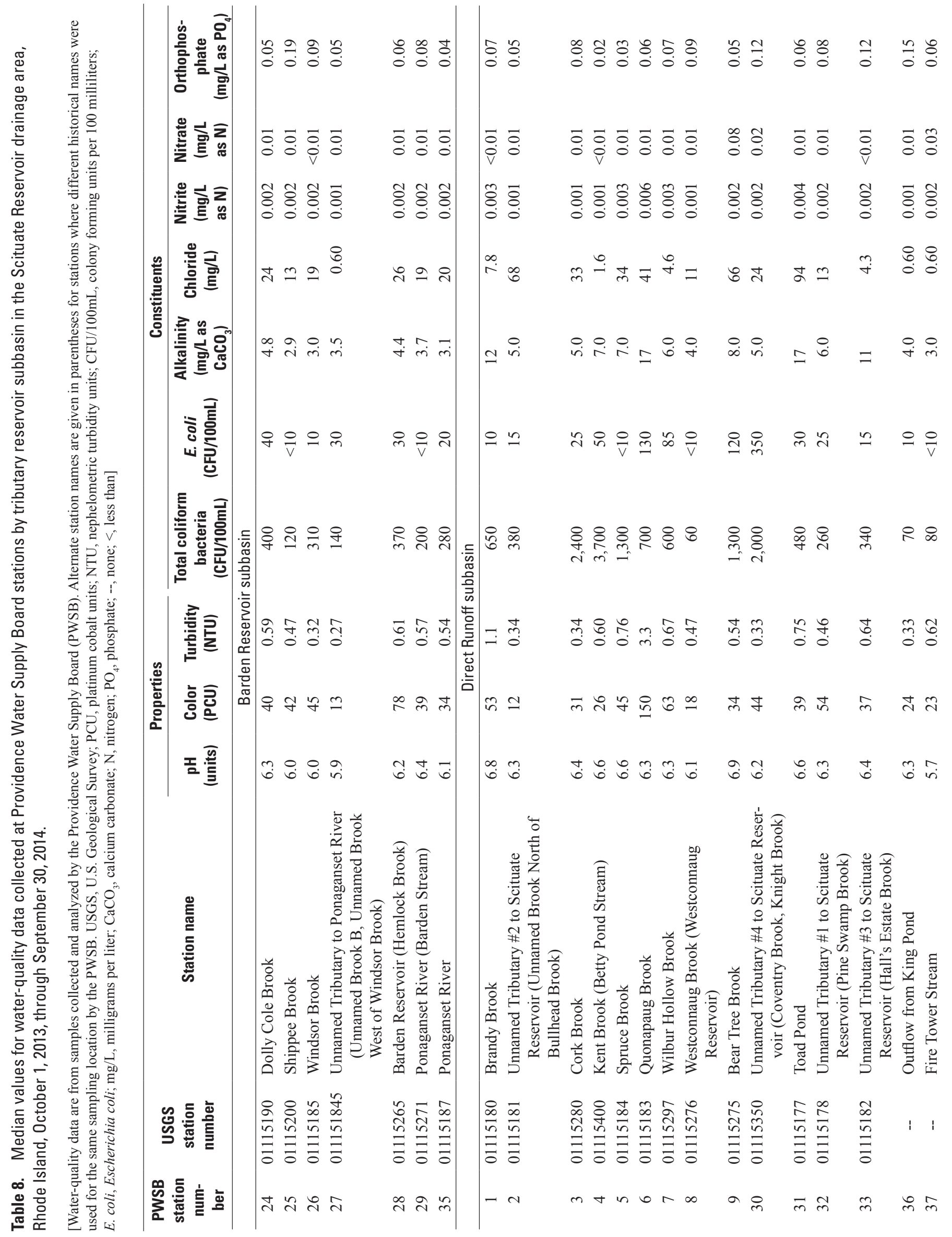




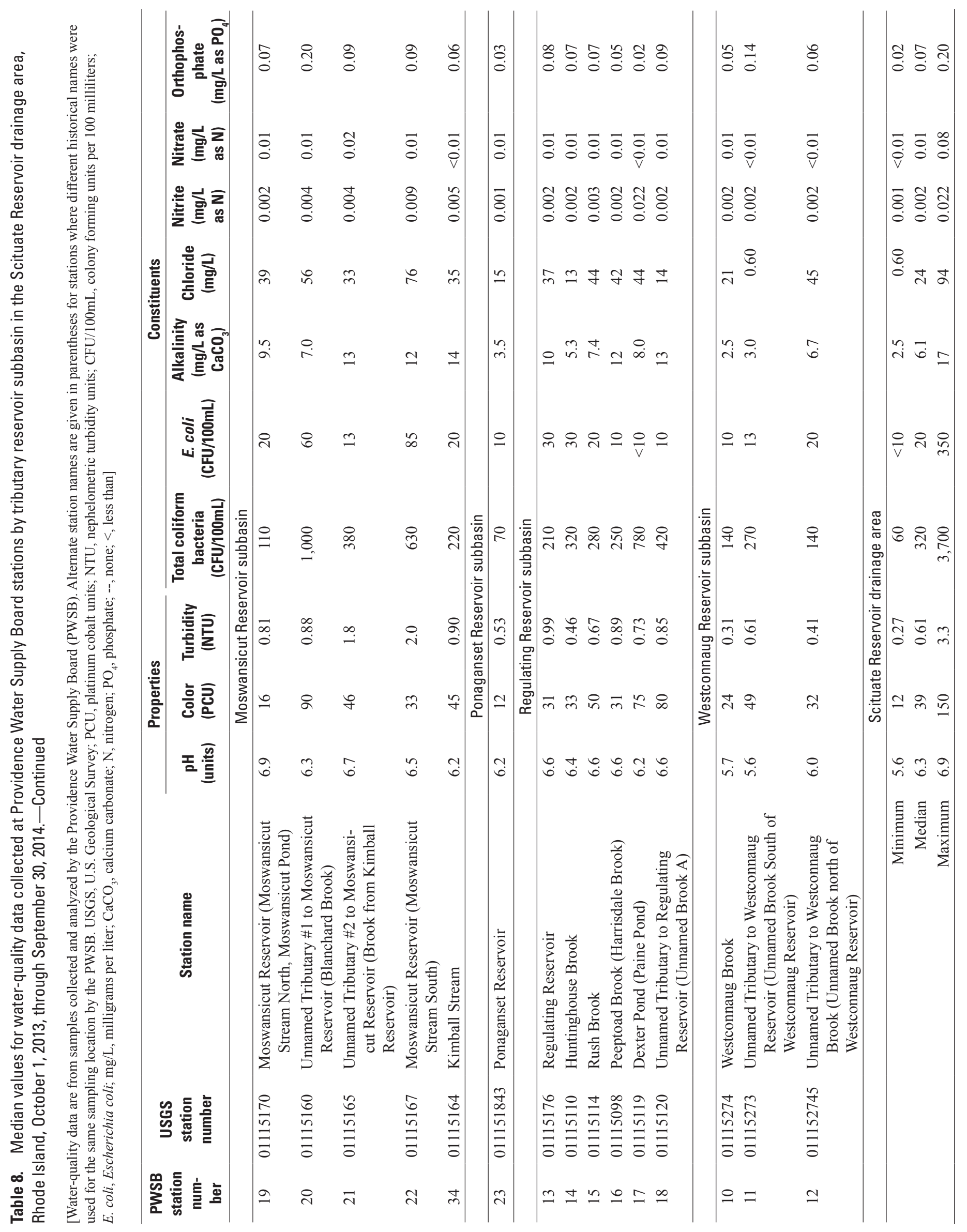




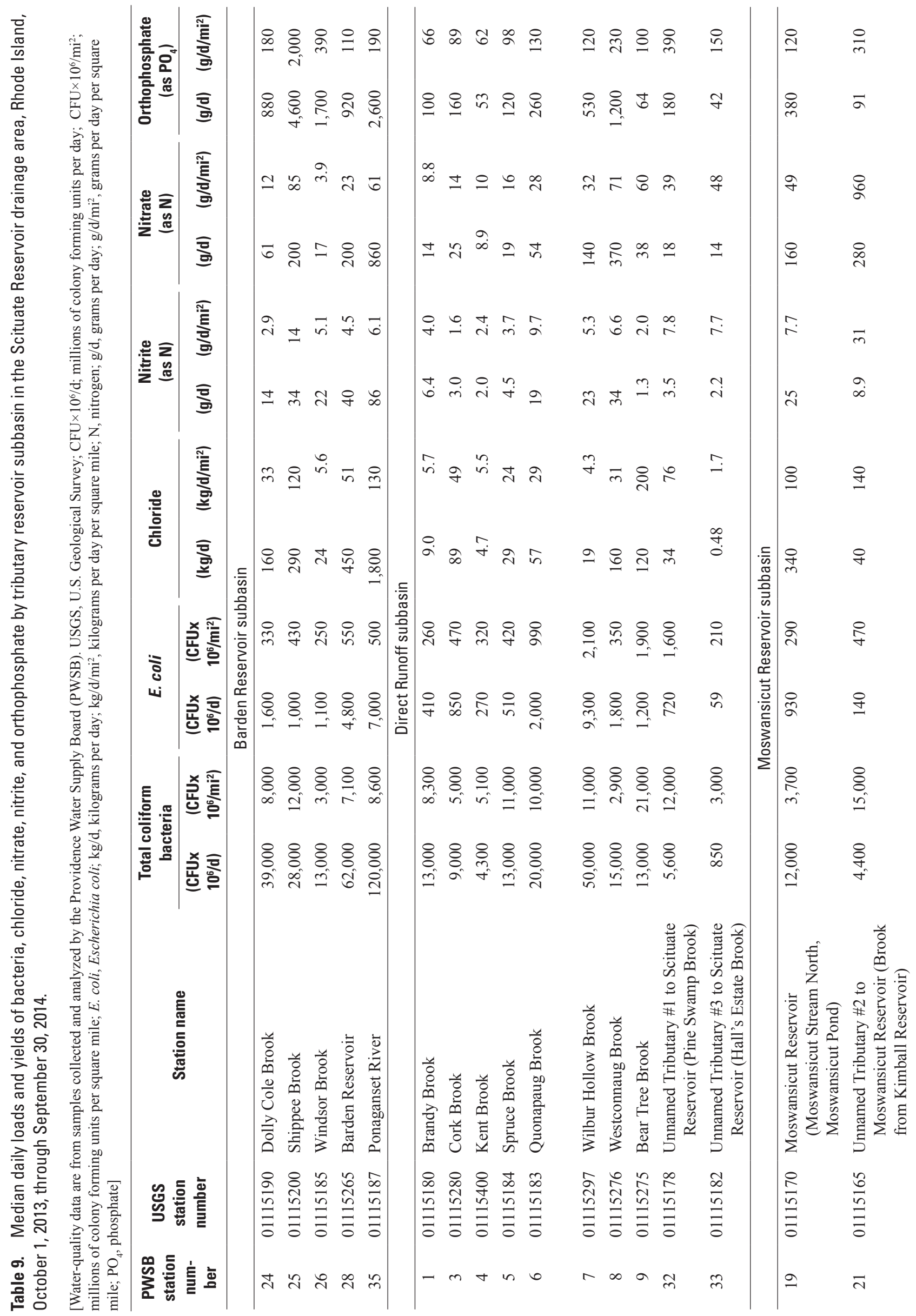


22 Streamflow, Water Quality, and Constituent Loads and Yields, Scituate Reservoir Drainage Area, Rhode Island, 2014

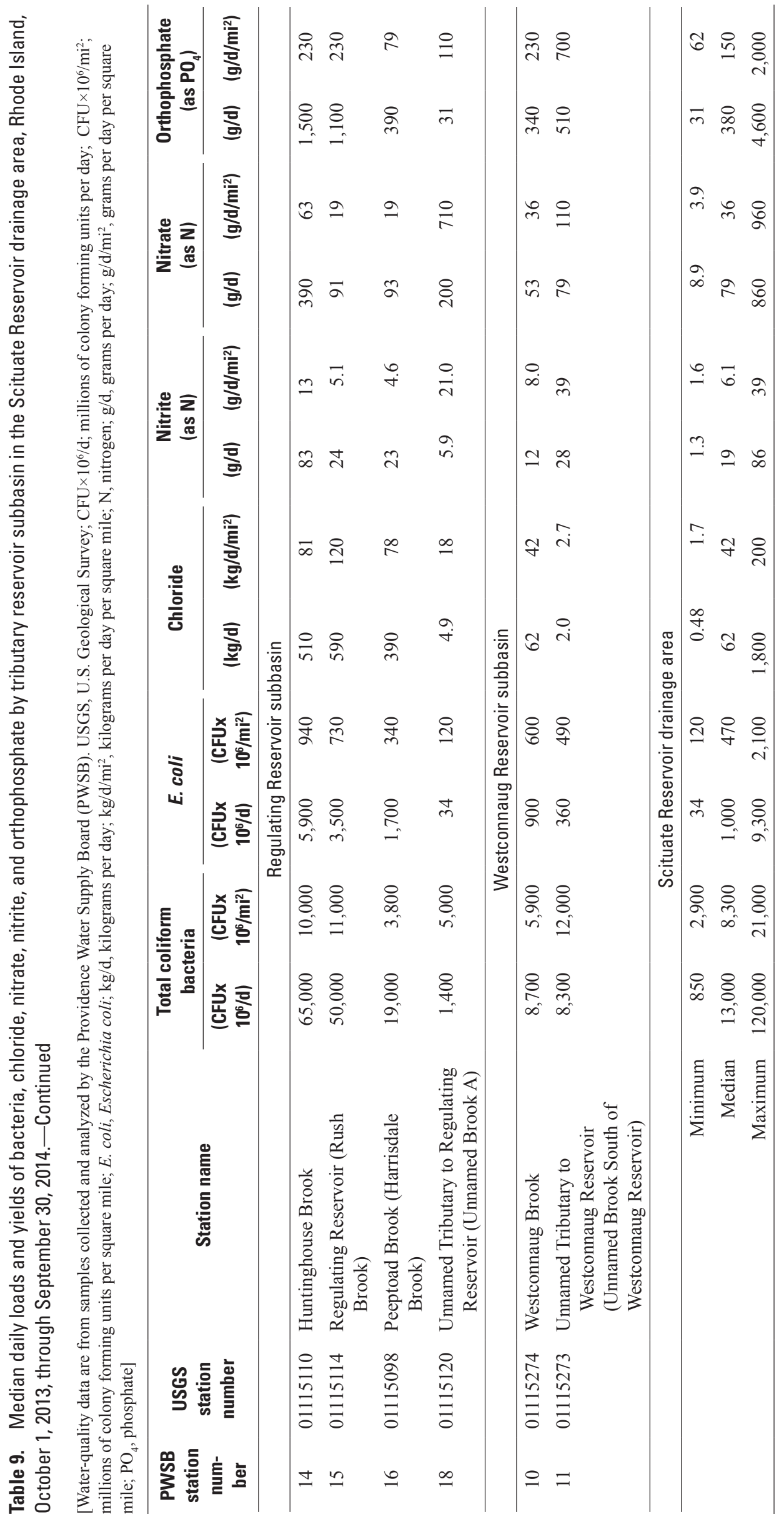


drainage area was 42 kilograms per day per square mile $\left(\mathrm{kg} / \mathrm{d} / \mathrm{mi}^{2}\right)$. Ponaganset River (PWSB station 35$)$ had the largest median daily chloride load (1,800 kilograms per day). The largest median daily chloride yield $\left(200 \mathrm{~kg} / \mathrm{d} / \mathrm{mi}^{2}\right)$ was determined for Bear Tree Brook (PWSB station 9). The mean daily yield of chloride and sodium for the drainage areas above the 14 USGS continuous-record streamgages, which represent nearly 66 percent of the Scituate Reservoir drainage area, was 90 and $55 \mathrm{~kg} / \mathrm{d} / \mathrm{mi}^{2}$, respectively. The mean daily yields of chloride and sodium for WY 2014 were similar to the annual mean yields for WY 2013 (94 and $57 \mathrm{~kg} / \mathrm{d} / \mathrm{mi}^{2}$, respectively; Smith, 2015a).

\section{Nutrients}

Median concentrations of nitrite and nitrate (table 8) were 0.002 and $0.01 \mathrm{mg} / \mathrm{L}$ as $\mathrm{N}$, respectively. The highest median concentration of nitrite $(0.022 \mathrm{mg} / \mathrm{L})$ was measured in a sample collected at Dexter Pond (PWSB station 17). The highest median concentration of nitrate $(0.08 \mathrm{mg} / \mathrm{L})$ was measured in a sample collected at Bear Tree Brook (PWSB station 9). The median concentration of orthophosphate for the entire study area (table 8) was $0.07 \mathrm{mg} / \mathrm{L}$ as phosphate $\left(\mathrm{PO}_{4}\right)$. The maximum median concentration of orthophosphate $\left(0.20 \mathrm{mg} / \mathrm{L}\right.$ as $\left.\mathrm{PO}_{4}\right)$ was measured in Unnamed Tributary \#1 to Moswansicut Reservoir (PWSB station 20). Median daily nitrite and nitrate loads were largest at Ponaganset River (PWSB station 35; 86 and 860 grams per day [g/d], respectively). The largest median daily phosphate load was determined for Shippee Brook (PWSB station 25; 4,600 g/d).

The largest median daily yield for nitrite ( 39 grams per day per square mile $\left[\mathrm{g} / \mathrm{d} / \mathrm{mi}^{2}\right]$ ) was determined for Unnamed Tributary to Westconnaug Reservoir (PWSB station 11). The largest median daily yield for nitrate $\left(960 \mathrm{~g} / \mathrm{d} / \mathrm{mi}^{2}\right)$ was determined for Unnamed Tributary \#2 to Moswansicut Reservoir (PWSB station 21), and the largest median daily yield for orthophosphate $\left(2,000 \mathrm{~g} / \mathrm{d} / \mathrm{mi}^{2}\right)$ was determined for Shippee Brook (PWSB station 25; table 9).

\section{References Cited}

Breault, R.F., 2010, Streamflow, water quality, and constituent loads and yields, Scituate Reservoir drainage area, Rhode Island, water year 2002: U.S. Geological Survey Open-File Report 2009-1041, 25 p.

Breault, R.F., and Campbell, J.P., 2010a, Streamflow, water quality, and constituent loads and yields, Scituate Reservoir drainage area, Rhode Island, water year 2003: U.S. Geological Survey Open-File Report 2010-1043, 24 p.
Breault, R.F., and Campbell, J.P., 2010b, Streamflow, water quality, and constituent loads and yields, Scituate Reservoir drainage area, Rhode Island, water year 2004: U.S. Geological Survey Open-File Report 2010-1044, 24 p.

Breault, R.F., and Campbell, J.P., 2010c, Streamflow, water quality, and constituent loads and yields, Scituate Reservoir drainage area, Rhode Island, water year 2005: U.S. Geological Survey Open-File Report 2010-1045, 24 p.

Breault, R.F., and Campbell, J.P., 2010d, Streamflow, water quality, and constituent loads and yields, Scituate Reservoir drainage area, Rhode Island, water year 2006: U.S. Geological Survey Open-File Report 2010-1046, 25 p.

Breault, R.F., and Smith, K.P., 2010, Streamflow, water quality, and constituent loads and yields, Scituate Reservoir drainage area, Rhode Island, water year 2009: U.S. Geological Survey Open-File Report 2010-1275, 24 p.

Breault, R.F., Sorenson, J.R., and Weiskel, P.K., 2002, Streamflow, water quality, and contaminant loads in the lower Charles River watershed, Massachusetts, 1999-2000: U.S. Geological Survey Water-Resources Investigations Report 02-4137, $131 \mathrm{p}$.

Breault, R.F., Waldron, M.C., Barlow, L.K., and Dickerman, D.C., 2000, Water-quality conditions in relation to drainage basin characteristics in the Scituate Reservoir Basin, Rhode Island, 1982-95: U.S. Geological Survey Water-Resources Investigations Report 00-4086, 46 p.

Helsel, D.R., and Hirsch, R.M., 2002, Statistical methods in water resources: U.S. Geological Survey Techniques of Water-Resources Investigations, book 4, chap. A3, 522 p.

Hirsch, R.M., 1982, A comparison of four streamflow record extension techniques: Water Resources Research, v. 18, no. 4, p. 1081-1088.

Hirsch, R.M., and Gilroy, E.J., 1984, Methods of fitting a straight line to data-Examples in water resources: Water Resources Bulletin, v. 20, no. 5, p. 705-711.

Nimiroski, M.T., DeSimone, L.A., and Waldron, M.C., 2008, Water-quality conditions and constituent loads, 1996-2002, and water-quality trends, 1983-2002, in the Scituate Reservoir drainage area, Rhode Island: U.S. Geological Survey Scientific Investigations Report 2008-5060, 55 p.

Nimiroski, M.T., and Waldron, M.C., 2002, Sources of sodium and chloride in the Scituate Reservoir drainage basin, Rhode Island: U.S. Geological Survey Water-Resources Investigations Report 02-4149, 16 p.

Providence Water Supply Board Water Quality Laboratory, 2012, Quality Assurance Program Manual: Providence Water Supply Board [variously paged]. 
Ries, K.G., III, and Friesz, P.J., 2000, Methods for estimating low-flow statistics for Massachusetts streams: U.S. Geological Survey Water-Resources Investigations Report 00-4136, $81 \mathrm{p}$.

Smith, K.P., 2013, Streamflow, water quality, and constituent loads and yields, Scituate Reservoir drainage area, Rhode Island, water year 2011: U.S. Geological Survey Open-File Report 2013-1127, 32 p.

Smith, K.P., 2014, Streamflow, water quality, and constituent loads and yields, Scituate Reservoir drainage area, Rhode Island, water year 2012: U.S. Geological Survey Open-File Report 2013-1274, 30 p.

Smith, K.P., 2015a, Streamflow, water quality, and constituent loads and yields, Scituate Reservoir drainage area, Rhode Island, water year 2013: U.S. Geological Survey Open-File Report 2015-1082, 31 p., accessed June 3, 2015, at http://dx.doi.org/10.3133/ofr20151082.

Smith, K.P., 2015b, Water-quality trends in the Scituate reservoir drainage area, Rhode Island, 1983-2012: U.S. Geological Survey Scientific Investigations Report 20155058, 57 p. [Also available at http://dx.doi.org/10.3133/ sir20155058.]
Smith, K.P., and Breault, R.F., 2011, Streamflow, water quality, and constituent loads and yields, Scituate Reservoir drainage area, Rhode Island, water year 2010: U.S. Geological Survey Open-File Report 2011-1076, 26 p.

Tasker, G.D., and Driver, N.E., 1988, Nationwide regression models for predicting urban runoff water quality at unmonitored sites: Water Resources Bulletin, v. 24, no. 5, p. 1090-1101.

U.S. Geological Survey, 2001, Water data for the nation: U.S. Geological Survey National Water Information System Web site, accessed November 10, 2010, at http://waterdata.usgs. gov/nwis/.

U.S. Geological Survey, 2007, Water-resources data for the United States, water year 2006: U.S. Geological Survey Water-Data Report WDR-US-2006, accessed November 5, 2009, at http://wdr.water.usgs.gov/.

Wagner, R.J., Boulger, R.W., Jr., Oblinger, C.J., and Smith, B.A., 2006, Guidelines and standard procedures for continuous water-quality monitors-Station operation, record computation, and data reporting: U.S. Geological Survey Techniques and Methods, book 1, chap. D3, 8 attachments, accessed April 10, 2006, at http://pubs.water.usgs.gov/ tm1d3. 


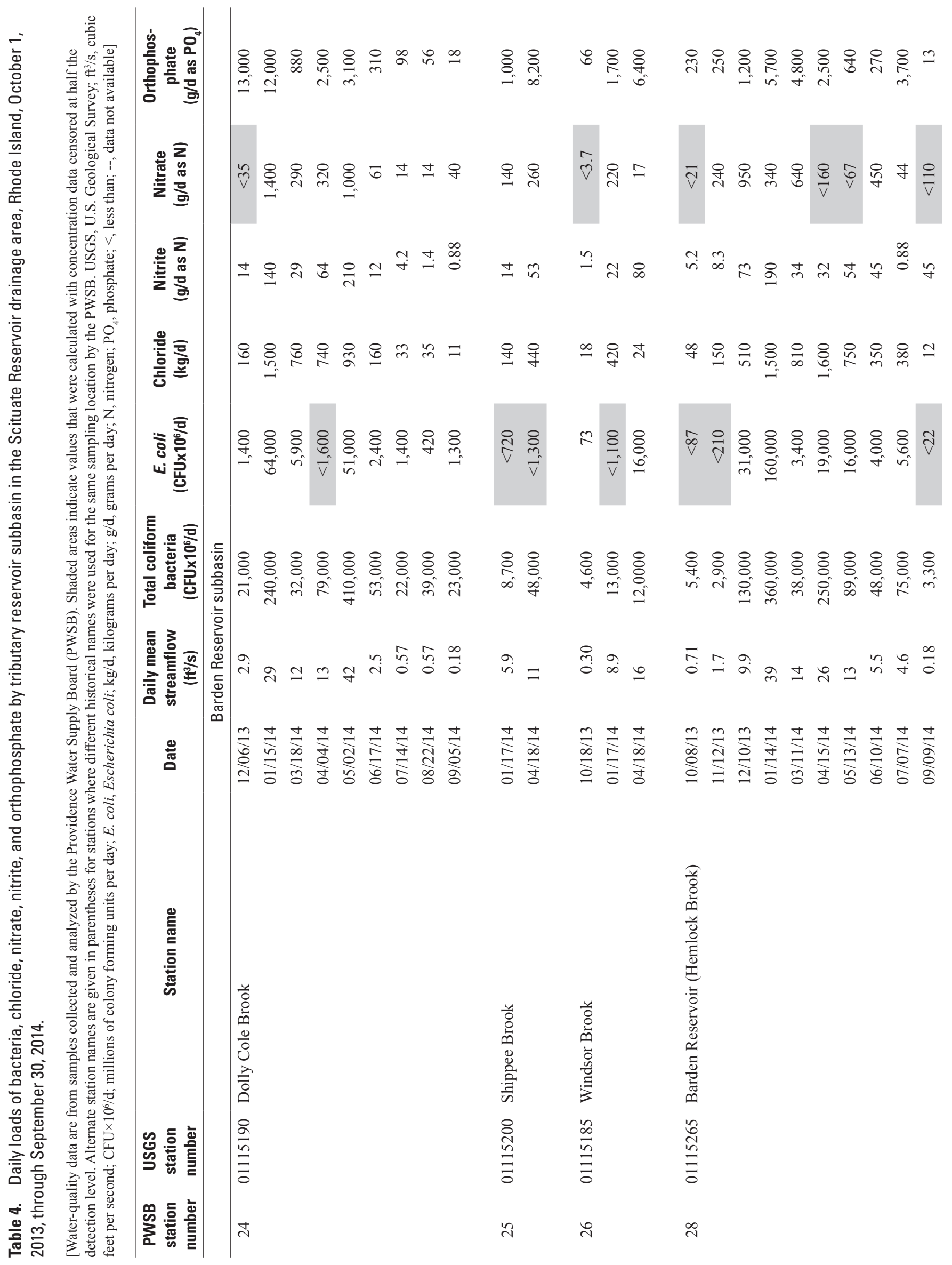




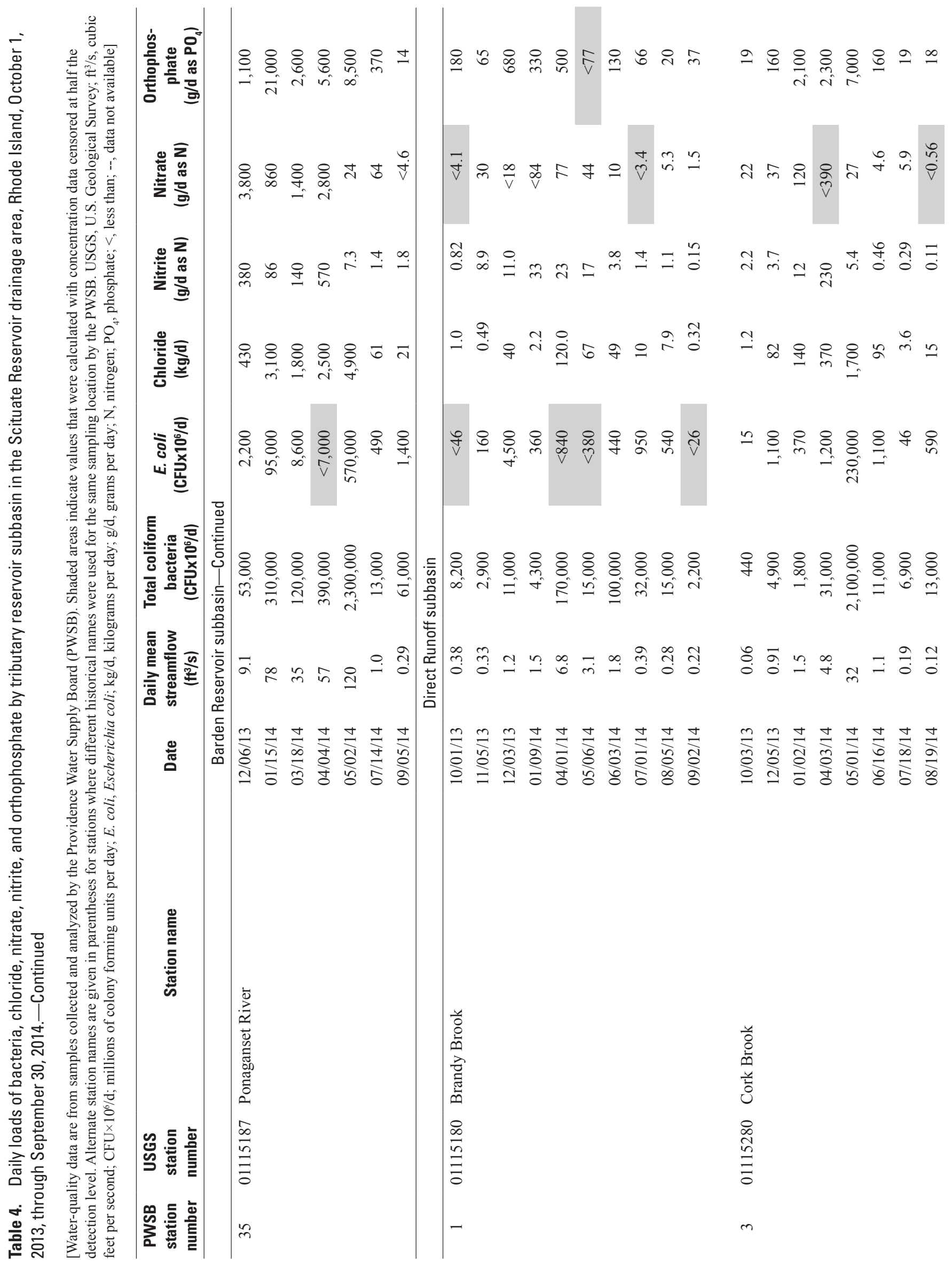




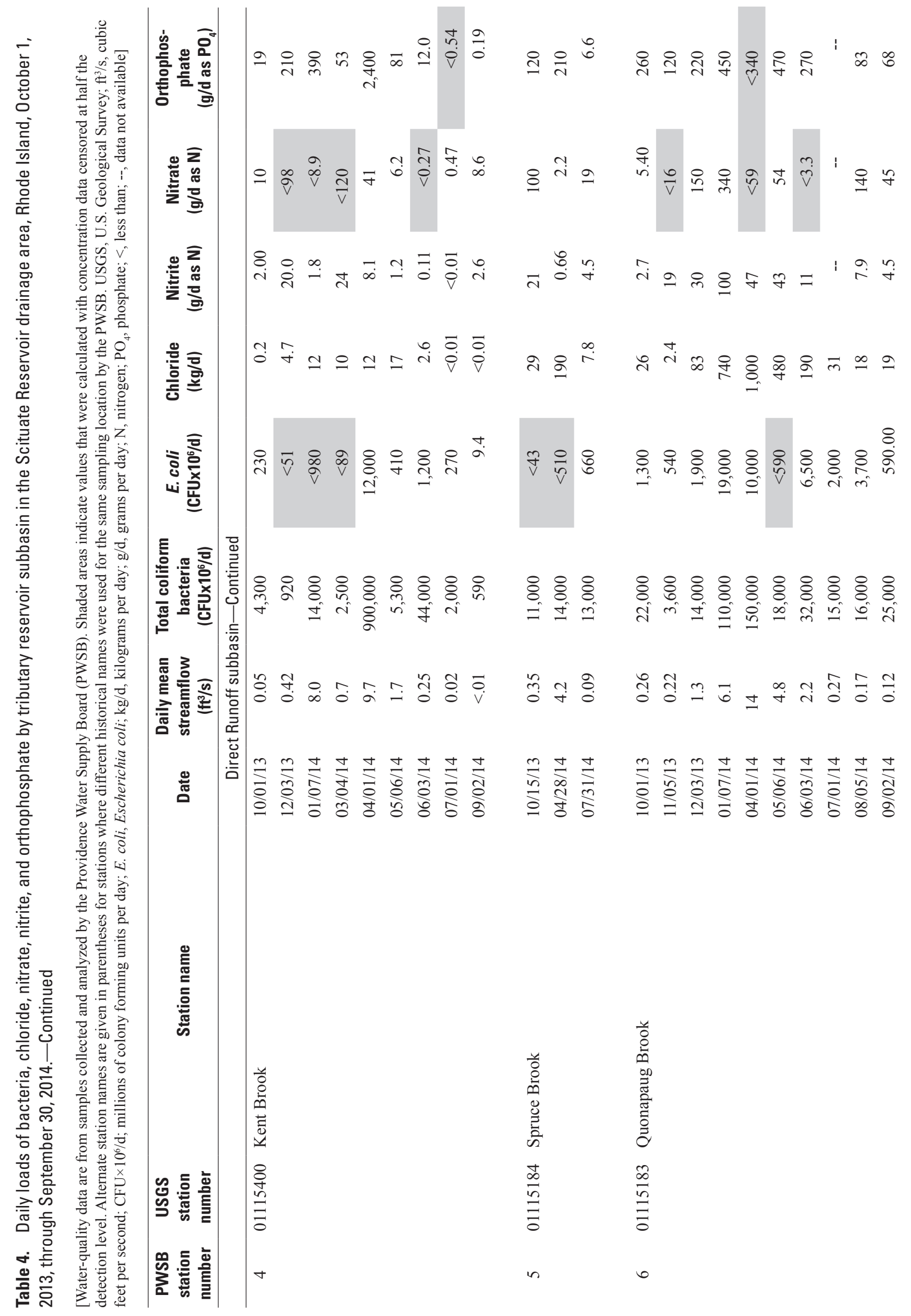




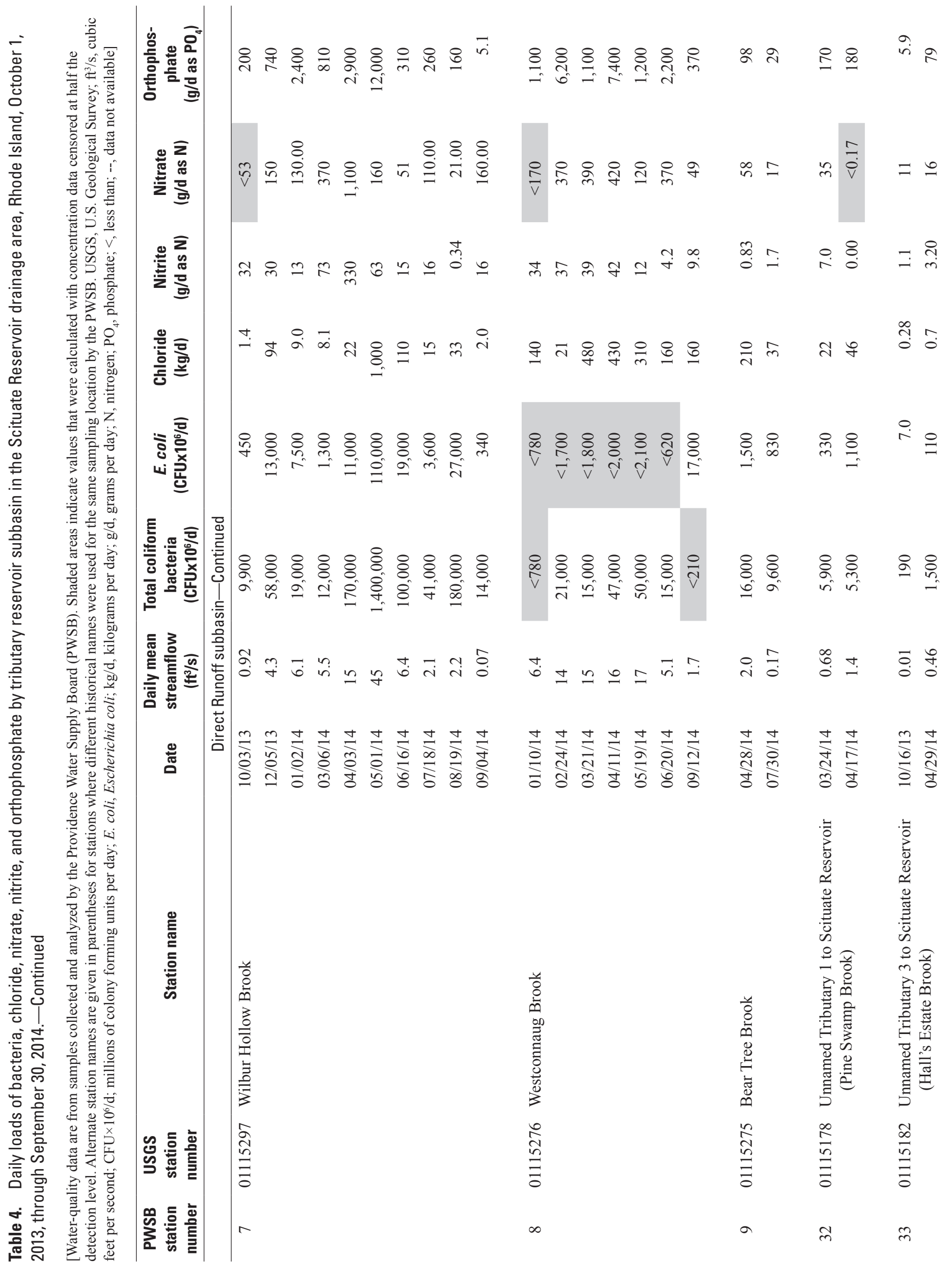




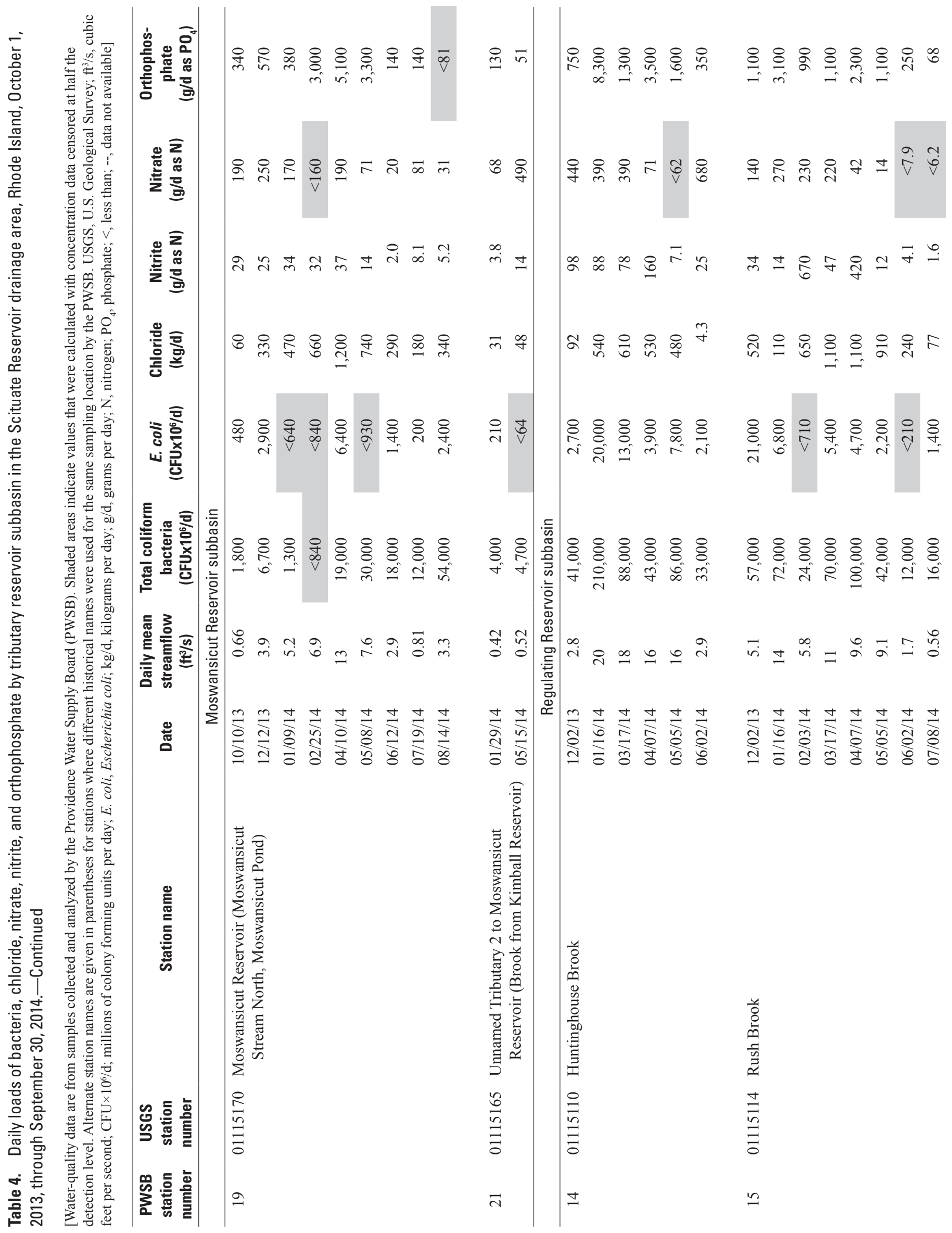




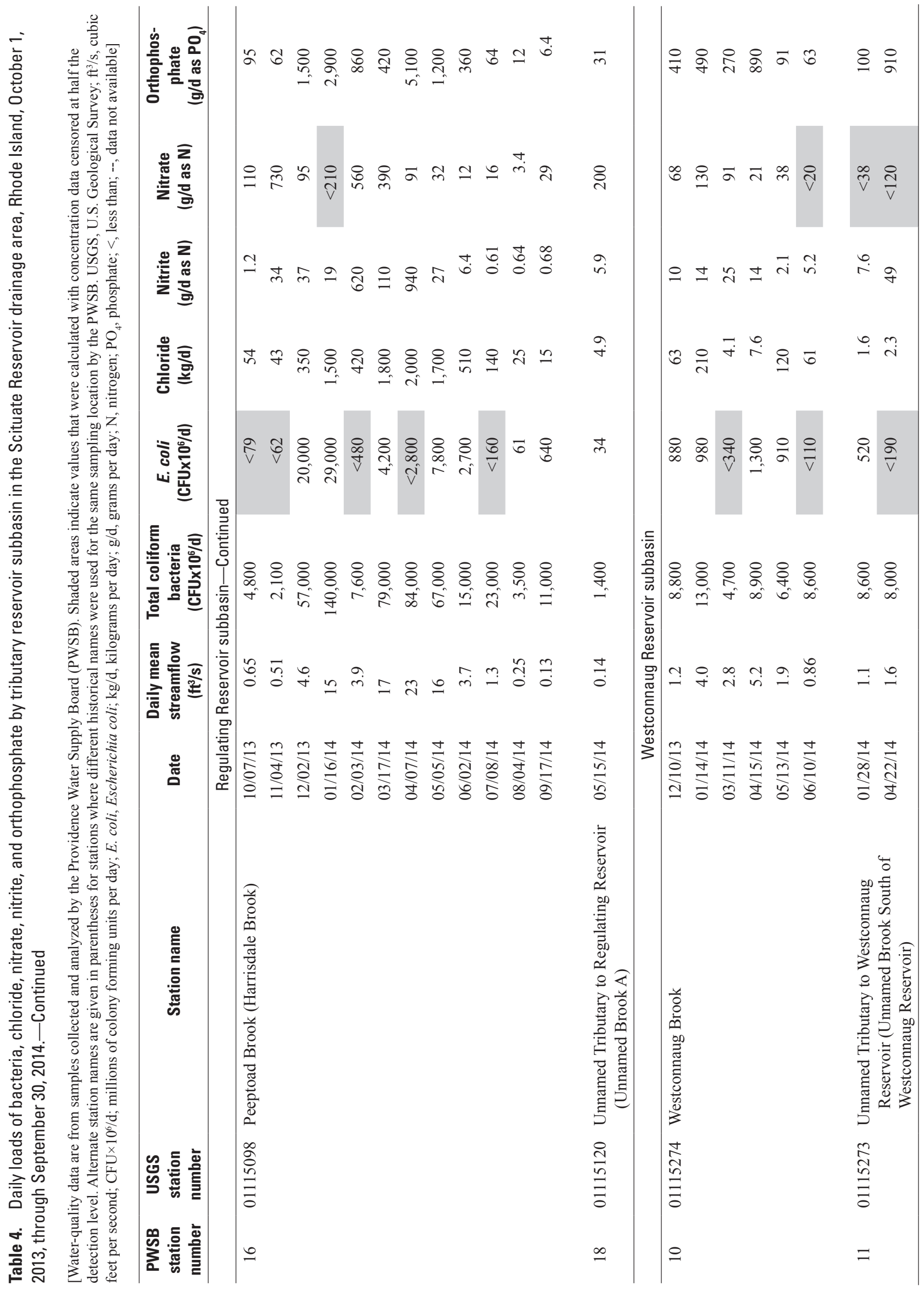




\section{Appendix 1. Water-Quality Data Collected by the Providence Water Supply Board at 37 Monitoring Stations in the Scituate Reservoir Drainage Area, Water Year 2014}

[Available as a separately downloaded Microsoft Excel file, at http://dx.doi.org/10.3133/ ofr20161051.] 

For more information concerning this report, contact: Director, New England Water Science Center U.S. Geological Survey 10 Bearfoot Road

Northborough, MA 01532

dc_nweng@usgs.gov or visit our Web site at: http://newengland.water.usgs.gov

Publishing support by:

The Pembroke Publishing Service Center 
